\title{
Catalytic Partial Oxidation of Methane on Platinum Investigated by Spatial Reactor Profiles, Spatially Resolved Spectroscopy, and Microkinetic Modeling
}

\author{
Oliver Korup ${ }^{\mathrm{a}}$, Claude Franklin Goldsmith ${ }^{\mathrm{a}}$, Gisela Weinberga ${ }^{\mathrm{a}}$, Michael Geske ${ }^{\mathrm{a}}$, Timur Kandemir ${ }^{\mathrm{a}}$, Robert Schlögl ${ }^{\mathrm{a}}$, \\ Raimund Horn ${ }^{\mathrm{a}, *}$ \\ ${ }^{a}$ Fritz Haber Institute of the Max Planck Society, Department of Inorganic Chemistry, Faradayweg 4-6, 14195 Berlin, Germany
}

\begin{abstract}
Spatially resolved profile measurements, Raman spectroscopy, electron microscopy, and microkinetic modeling have been used to study the catalytic partial oxidation of methane on Pt. The measured species profiles through Pt coated foam catalysts exhibit a two-zone structure: an abrupt change in reaction rates separates the fast exothermic oxidation chemistry at the entrance of the reactor from the slow endothermic reforming chemistry. Spatially resolved Raman spectroscopy and electron microscopy confirm that the position of the mechanistic change could be correlated with Pt transportation and formation of carbonaceous deposits blocking the majority of active Pt sites in the reforming zone. The species profiles were simulated using a pseudo-2D heterogeneous model, which includes heat and mass transport limitations, and two state-of-the-art chemical kinetic mechanisms. Although both mechanisms are in quantitative agreement with the oxygen profiles, the two mechanisms differ substantially in their predictions of the branching ratio between partial and complete oxidation, as well as surface site coverages. The experimentally observed change in reaction rates is attributed to carbon formation, which the mechanisms are unable to reproduce, since they do not include carbon-carbon coupling reactions.
\end{abstract}

Keywords: catalytic partial oxidation, methane, synthesis gas, platinum, microkinetic modeling, carbon formation, Raman spectroscopy, electron microscopy

\section{Introduction}

Methane steam reforming (Eq. 1) is currently the dominant technology for synthesis gas production [1]. The process is highly endothermic, and industrial production requires large and capital-intensive operations. Catalytic partial oxidation (CPO) of methane (Eq. 2) is an attractive alternative, since it is slightly exothermic and considerably faster, with nearly equilibrium yields in synthesis gas within millisecond contact times [2-5], possibly in autothermal operation.

$$
\begin{aligned}
\mathrm{CH}_{4}+\mathrm{H}_{2} \mathrm{O} \rightarrow \mathrm{CO}+3 \mathrm{H}_{2} & \Delta_{r} \mathrm{H}^{\ominus}=+206 \mathrm{~kJ} \mathrm{~mol}^{-1} \\
\mathrm{CH}_{4}+\frac{1}{2} \mathrm{O}_{2} \rightarrow \mathrm{CO}+2 \mathrm{H}_{2} & \Delta_{r} \mathrm{H}^{\ominus}=-36 \mathrm{~kJ} \mathrm{~mol}^{-1} \\
\mathrm{CH}_{4}+2 \mathrm{O}_{2} \rightarrow \mathrm{CO}_{2}+2 \mathrm{H}_{2} \mathrm{O} & \Delta_{r} \mathrm{H}^{\ominus}=-803 \mathrm{~kJ} \mathrm{~mol}^{-1} \\
\mathrm{CH}_{4}+\mathrm{CO}_{2} \rightarrow 2 \mathrm{CO}+2 \mathrm{H}_{2} & \Delta_{r} \mathrm{H}^{\ominus}=+247 \mathrm{~kJ} \mathrm{~mol}^{-1}
\end{aligned}
$$

The global mechanism by which methane is oxidized to synthesis gas on noble metal catalysts is frequently debated in the literature. One school of thought suggests that the mechanism must be a two-step process that consists of initially highly exothermic methane complete oxidation (Eq. 3) followed by endothermic reforming reactions, i.e. steam (Eq. 1) and dry reforming (Eq. 4). The

\footnotetext{
* Corresponding author

Email address: horn_r@fhi-berlin.mpg.de (Raimund Horn)
}

main argument is a commonly observed steep temperature gradient over the catalyst bed $[6,7]$. Investigations of product selectivities demonstrated that the $\mathrm{CO}_{2}$ and $\mathrm{H}_{2} \mathrm{O}$ selectivity increased with simultaneous synthesis gas loss by either increasing the space velocity or increasing the $\mathrm{O}_{2} / \mathrm{CH}_{4}$ ratio [7-9]. Additionally, transient experiments did not indicate a direct reaction pathway [10-12]. In contrast, authors proposed a single step process. Experiments on $\mathrm{Pt}$ and $\mathrm{Pt} / 10 \% \mathrm{Rh}$ meshes and millisecond contact time suggest a direct reaction pathway, as the increasing synthesis gas selectivity with decreasing contact time cannot be explained by the two step mechanism [5, 13-15]. Due to the exothermicity and rapidness of catalytic methane oxidation, differential reactant conversion cannot be achieved; furthermore, irreducible transport limitations exist under these conditions. Consequently, classical kinetic studies by contact time variations are nearly impossible, since changing flow rates leads to unclear transport characteristics and hot spot formation. Furthermore, discussions that rely on global mechanism descriptions can be misleading, since in reality the catalytic partial oxidation of methane is neither a single-step nor two-step process, but a mechanism involving dozens of elementary reactions. Which product channels are favored at a given position is a complex function of the reaction rates, which in turn are influenced by the chemical potential of the gases in contact with the surface. Microkinetic modeling - using a chemical kinetic 
mechanism composed of reactive intermediates and elementary reactions, coupled with a description of the flow field including heat- and mass-transport limitations - is a valuable tool in resolving the debate over CPO. A properly validated microkinetic model can be used not only to answer questions regarding the underlying mechanism, but it can also be used to predict product yields under new reactor conditions, potentially saving time and money.

High-resolution reactor profiles can be measured via the capillary sampling technique developed by Horn et al. [16], providing profiles of species and temperature with submillimeter resolution. The reactant conversion and product formation can be followed as a function of position, and the obtained reactor profiles can be used for testing of kinetic models.

The previous work on methane CPO on Rh and Pt supported on ceramic foam monoliths [16-19] gave clear evidence that both partial and complete methane oxidation proceeds in parallel in a narrow oxidation zone at the entrance of the catalyst foam. This oxidation zone is followed by a longer endothermic steam reforming zone, and at sufficiently low catalyst temperatures, water gas shift is also observed. Dry reforming does not have a significant impact. The studies found Rh superior in synthesis gas selectivity over $\mathrm{Pt}[17,18]$, and no catalyst deactivation was observed over the investigated time period. The high synthesis gas selectivity on the Rh catalyst was investigated by microkinetic modeling with consideration of transport phenomena $[19,20]$. A strong transport limitation within the oxidation zone was found. It was concluded that the coexistence of $\mathrm{H}_{2}$ and $\mathrm{CO}$ in the oxidation zone in presence of $\mathrm{O}_{2}$ and at the high local temperatures is due to a strong $\mathrm{O}_{2}$ deficit at the Rh surface. For Pt such a detailed analysis is missing so far.

Recently it was suggested that the transport limitations for a Pt-coated foam monolith are less pronounced than on a Rh-coated foam monolith under similar conditions [21]. Nonetheless, a significant selectivity to synthesis gas can be achieved with the Pt catalyst in the presence of gas phase oxygen.

In this paper methane $\mathrm{CPO}$ on Pt coated foam monoliths is investigated. A pseudo-2D heterogeneous reactor model accounting for mass and heat transport has been developed and is combined with two state-of-the-art microkinetic models. The microkinetic models are tested against high resolution spatial reactor profiles. Peculiar features in the species profiles have been investigated by spatially resolved Raman spectroscopy and electron microscopy providing new impulses for model improvements.

\section{Experimental}

\subsection{Catalyst Preparation}

The catalysts used in this study are Pt coated, cylindrical $\alpha-\mathrm{Al}_{2} \mathrm{O}_{3}$ foam monoliths with a pore density of $80 \mathrm{ppi}$ (pores per linear inch). The monoliths (length $=20 \mathrm{~mm}$ and diameter $=16.2 \mathrm{~mm}$ ) were prepared by incipient wetness impregnation with aqueous $\mathrm{H}_{2} \mathrm{PtCl}_{6}$ as precursor. Prior to impregnation the foam support was cut to the desired length and a centerline channel of $1 \mathrm{~mm}$ diameter was drilled through the foam. The foams were washed in acetone in order to remove any residuals from the cooling fluid, then boiled in nitric acid to remove possible metal contaminations from the drilling and confectioning step. Next the support was dried and calcined at $800^{\circ} \mathrm{C}$ in static air. The impregnation was done in a multi-step approach, in which the foams were soaked in the precursor solution by dropwise addition of liquid on the foams. The precursor solution consisted of $7 \mathrm{ml}$ deionized water (Millipore) and the equivalent amount of $\mathrm{H}_{2} \mathrm{PtCl}_{6} \cdot 6 \mathrm{H}_{2} \mathrm{O}$ (Alfa Aesar, $99.95 \%$ purity, 37-40\% Pt content) corresponding to a nominal $\mathrm{Pt}$ loading of $1 \mathrm{wt} \%$. The freshly impregnated foams were then vacuum dried at room temperature over night, and the procedure was repeated until the entire precursor solution had been applied. After the last drying step the foams were reduced in a tubular furnace in $7 \mathrm{vol} \% \mathrm{H}_{2}$ in $\mathrm{Ar}\left(\dot{V}_{\text {total }}=3000 \mathrm{mln} \mathrm{min}^{-1}\right)$ at a monolith core temperature of $500{ }^{\circ} \mathrm{C}$ for $5 \mathrm{~h}$. After reduction the $\mathrm{Pt}$ loading was determined by gravimetry. An average loading of $1 \mathrm{wt} \% \mathrm{Pt}$ was found.

\subsection{Catalytic Testing}

The capillary sampling technique used in the present work has been described in detail previously [16], and only a brief summary will be provided here. The reactor uses a fused silica capillary with side orifice to sample a small gas volume from the centerline symmetry axis of the catalyst bed and to transfer it to the gas analytic devices. Here, online gas analytics were accomplished by a calibrated mass spectrometer (Pfeiffer Vacuum) operated in analog scan mode and applying the Ar peak at $m / z=40$ as internal standard. The sampling capillary additionally accommodates an optical fused silica fiber with conical shaped tip connected to a two-color ratio pyrometer. The sampling capillary/pyrometer tip probe allows for simultaneous species analysis with surface temperature measurements through the catalyst bed. The catalysts were operated under auto-thermal operation conditions.

In the present work two distinct catalyst foams were investigated: One foam was left intact, whereas a second foam was sliced in half lengthwise prior to impregnation (see Section 4.2 for details). Both monoliths were tested in the same way. The catalyst foam monoliths were sandwiched in between two clean 80 ppi foam monoliths of $10 \mathrm{~mm}$ length serving as heat shields to reduce radiative heat losses. Fig. 1 depicts the catalyst stack made up by two half monoliths prior to installation in the reactor. The catalyst stack was wrapped in a ceramic mate $(3 \mathrm{M}$ Interam) and gas tightly fit in the center of the reactor tube. Next, the stack was heated in reaction atmosphere until reaction light-off. Subsequently, the reactor furnace 


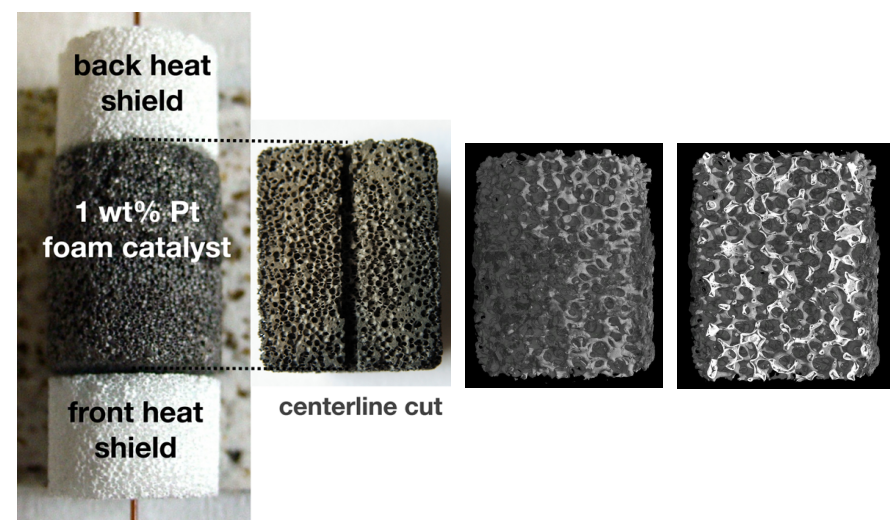

Figure 1: Left: Photograph of catalyst stack before reaction test, with one half foam monolith showing the centerline channel. Right: Foam structure visualization of the reconstruction of an intact foam monolith from X-ray $\mu$-CT (overview and intermediate cut). For better visualization $\mu$-CTs from a 45 ppi foam are shown.

was switched off and profiles were measured after the furnace temperature reached a steady state in autothermal reactor operation.

\subsection{Catalyst Characterization}

After catalytic testing, the foam monoliths were characterized by means of geometric, BET and Pt surface area, as well as by metal dispersion and Pt crystallite size.

To determine the fluid-dynamically relevant foam surface area, i.e. geometric surface area of the struts, lab X-ray micro-computer-tomography $(\mu$-CT) was applied. The $\mu$ CT apparatus $[22,23]$ used to characterize the foam monolith consisted of a micro-focus $150 \mathrm{kV}$ X-ray source with a tungsten target and a flat $120 \times 120 \mathrm{~mm}^{2}$ panel detector, both from Hamamatsu. Source and detector are static in this setup and the foam monolith was rotated by $360^{\circ}$, while every $0.28^{\circ}$ a projection was acquired. Using the Octopus V8.5 software [24] the foam volume was reconstructed. The corresponding voxel size of the reconstructed volume is $15 \mu \mathrm{m}$. The geometric surface area was determined using VGStudio MAX V2.1 [25].

Because the struts of the ceramic foam are not ideally flat, but contain a certain amount of surface roughness, cracks, and fractures, the effective surface area differs by approximately one to two orders of magnitude from the geometric surface area by $\mu$-CT $[26,27]$ and needs to be determined by a complementary technique. The effective surface area was therefore determined by isothermal adsorption of krypton at $77 \mathrm{~K}$ by the static-volumetric method (Quantachrom Autosorb-1).

The accessible Pt surface area and metal dispersion were measured on coarsely crushed samples after the reaction tests by determining the hydrogen monolayer coverage capacity by chemisorption at $40{ }^{\circ} \mathrm{C}$ in a Quantachrom Autosorb1 apparatus. How the different surface areas are utilized in microkinetic modeling is specified in Section 3.

Raman spectra presented in this work were recorded by a triple filter Raman spectrometer (TriVista S\&I GmbH) with a liquid nitrogen cooled CCD camera (Princeton Instruments) as detector. The spectrometer was attached to a confocal microscope (Olympus, $10 \times$ long-working distance objective), using an $\mathrm{Ar}^{+}$laser with $\lambda=488 \mathrm{~nm}$ excitation wavelength $(2.2 \mathrm{~mW}$ on the sample). The microscope is equipped with a motorized optical table that allows reproducible positioning with $\mu \mathrm{m}$ resolution. The spectrometer was operated in triple subtractive mode and each spectrum was integrated for $10 \mathrm{~min}$. A two point wavelength calibration was used (laser wavelength and firstorder Stokes phonon band of Si at $520 \mathrm{~cm}^{-1}$ ). The Raman spectra included a broad continuum like background, which was subtracted applying the method of Gornushkin et al. [28].

To add additional topographical and morphological information of the catalyst and support, scanning electron microscopy was applied to the half monolith sample, prior to and after reaction test. A Hitachi S-4800 FEG (cold) SEM was used. Due to interference by charging of the mostly insulating catalyst foams a FEI Quanta 200 FEG (hot) ESEM was used to address these perturbations, if necessary. A low vacuum with $60 \mathrm{~Pa}$ water pressure was applied. Both SEMs are equipped with an EDAX Genesis 4000 System (Vers. 6.1) and an energy dispersive X-ray detector.

The Pt particle size was determined after reaction tests and powdering the foam monolith by full powder XRD pattern fitting using the Rietveld method. The integral breadth-based volume weighted mean crystallite size (L Vol-IB) of Pt was determined assuming that all Pt particles are spherical and single domain. The particle diameter $d$ is given by

$$
d=4 / 3 \text { LVol-IB }
$$

Powder XRD was measured on a Bruker D8 Advance theta/ theta diffractometer.

\section{Numerical Modeling}

\subsection{Model Equations}

To model the detailed chemistry for methane partial oxidation inside a Pt-coated $\alpha$-alumina foam monolith, a pseudo-2D heterogeneous reactor model including transport phenomena is used. The system consists of three phases: a bulk gas phase, a boundary layer gas phase, and a chemically reactive surface. The coupling between chemistry and transport is modeled using a simplified system of Navier-Stokes equations for the conservation of mass, momentum, and energy, including conservation equations for $N_{\text {gas }}$ gas-phase species in the gas bulk and in the gas boundary layer and $N_{\text {surface }}$ surface species on the surface. Gas-phase reactions are neglected, because they are not significant at atmospheric pressure [19, 20, 29]. In the following, the bulk gas phase is denoted with no subscript; the surface is denoted with a subscript $s$; and boundary 


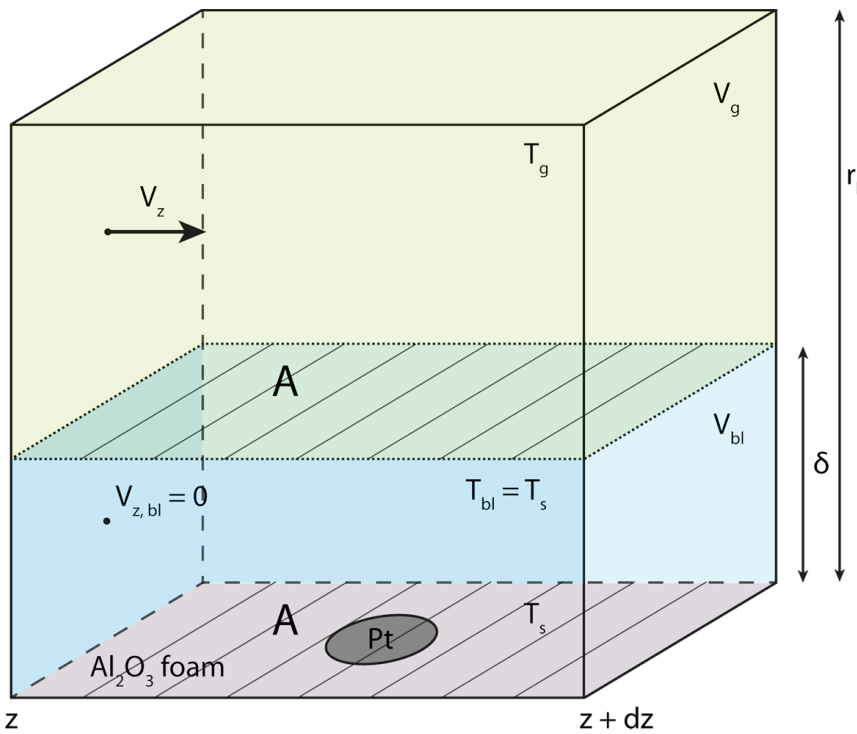

Figure 2: Sketch of volume element illustrating the modeling domains. $\delta$ strongly exaggerated for illustration purpose $\left(\delta<<r_{\mathrm{h}}\right)$.

layer variables are denoted with a subscript $b l$. Fig. 2 depicts schematically the modeling domains. In this work the following simplifying assumptions have been made:

1. The gases are ideal.

2. Given the high flow rates of the gas, the radial symmetry, the small pore diameter, and the high heattransfer rates of the foam, we assume that there are no spatial gradients in the $r$ and $\phi$ direction: $\nabla x=\frac{\partial x_{z}}{\partial z} \overrightarrow{e_{z}}$.

3. There is convective transport in the bulk gas phase, but no convective transport in the boundary layer: $v=v_{z}, v_{z, b l}=0$.

4. The boundary layer is assumed to be thin enough that the surface area of the boundary layer is equal to the surface area of the foam: $A_{b l}=A_{\mathrm{s}}=A$.

5. The small cracks and pores within the surface are assumed to be inaccessible during operation. Consequently, the relevant surface-area-to-volume ratio, $S_{v}$, is assumed to be the geometric surface-area-tovolume ratio determined from the $\mu$-CT study.

6 . The percentage of the surface area that is catalytically active, $f_{\text {active, }}$ is taken to be the ratio of the surface areas from the $\mathrm{H}_{2}$ chemisorption and $\mathrm{Kr}$ adsorption measurements.

7. Species are transported between the bulk gas phase and the boundary layer gas phase. The mass flow rate is assumed to be proportional to the surface area times the difference in mass density across the boundary: $\sim A K_{k}\left(\rho_{i}-\rho_{i, b l}\right)$.

8. The mass and heat transport coefficients $K_{k}$ and $K_{T}$ across the boundary layer are estimated from the Sherwood number and the Nusselt number, respectively.

9. Only the boundary-layer gases are coupled with the surface.
10. The pressure is constant, and pressure drop along the length of the reactor is negligible.

11. The boundary layer volume is constant: $d V=-d V_{b l}=$ 0 .

12. The boundary layer temperature is equal to the surface temperature, which is assumed to be equal to the pyrometer reading: $T_{b l}=T_{s}=T_{\text {pyrometer }}$.

All equations are written on a void volume basis, and symbols are explained in the Nomenclature at the end of the document:

Equation of state:

$$
\rho=\frac{p \bar{W}}{R T}
$$

Conservation of mass:

$$
\begin{aligned}
\frac{\partial \rho}{\partial t}= & -\frac{\partial \rho v_{z}}{\partial z}-\frac{S_{v}}{\gamma} \sum_{k}^{N_{g a s}} K_{k}\left(\rho y_{k}-\rho_{b l} y_{k, b l}\right) \\
\frac{\partial \rho_{b l}}{\partial t}= & \frac{S_{v}}{1-\gamma} \sum_{k}^{N_{\text {gas }}} K_{k}\left(\rho y_{k}-\rho_{b l} y_{k, b l}\right) \\
& +\frac{f_{\text {active }} S_{v}}{1-\gamma} \sum_{k}^{N_{\text {gas }}} \dot{s}_{k, b l} W_{k}
\end{aligned}
$$

Conservation of momentum:

$$
\frac{\partial v_{z}}{\partial t}=-\frac{v_{z}}{\rho}\left(\frac{\partial \rho}{\partial t}+\frac{\partial \rho v_{z}}{\partial z}\right)-v_{z} \frac{\partial v_{z}}{\partial z}+\frac{\epsilon}{\tau} \frac{\partial}{\partial z}\left(\mu \frac{\partial v_{z}}{\partial z}\right)
$$

Conservation of species in the bulk gas:

$$
\begin{aligned}
\frac{\partial y_{k}}{\partial t}= & -v_{z} \frac{\partial y_{k}}{\partial z}-\frac{1}{\rho} \frac{\partial j_{k, z}}{\partial z}-\frac{y_{k}}{\rho}\left(\frac{\partial \rho}{\partial t}+\frac{\partial \rho v_{z}}{\partial z}\right) \\
& +\frac{1}{\rho} \dot{w}_{k} W_{k}-\frac{1}{\rho} \frac{S_{v}}{\gamma} K_{k}\left(\rho y_{k}-\rho_{b l} y_{k, b l}\right) \\
y_{\text {bath gas }}= & 1-\sum_{k \neq \text { bath gas }}^{N_{\text {gas }}} y_{k}
\end{aligned}
$$

Conservation of species in the boundary layer:

$$
\begin{aligned}
\frac{\partial y_{k, b l}}{\partial t}= & -\frac{1}{\rho_{b l}} \frac{\partial j_{k, z, b l}}{\partial z}-\frac{y_{k, b l}}{\rho_{b l}} \frac{\partial \rho_{k, b l}}{\partial t}+\frac{1}{\rho_{b l}} \dot{w}_{k, b l} W_{k} \\
& +\frac{1}{\rho_{b l}} \frac{f_{a c t i v e} S_{v}}{1-\gamma} \dot{s}_{k, b l} W_{k} \\
& +\frac{1}{\rho_{b l}} \frac{S_{v}}{1-\gamma} K_{k}\left(\rho y_{k}-\rho_{b l} y_{k, b l}\right) \\
y_{\text {bath gas }, b l}= & 1-\sum_{k \neq \text { bath gas }}^{N_{\text {gas }}} y_{k, b l}
\end{aligned}
$$

Conservation of species on the surface:

$$
\begin{aligned}
\frac{d \theta_{k}}{d t} & =\frac{\dot{s}_{k} \sigma_{k}}{\Gamma} \\
\theta_{\mathrm{Pt}} & =1-\sum_{k \neq \mathrm{Pt}}^{N_{\text {surf }}} \theta_{k}
\end{aligned}
$$


Conservation of energy in the bulk gas phase:

$$
\begin{aligned}
\rho c_{p} \frac{\partial T}{\partial t}= & -\frac{\partial T}{\partial z}\left(\sum_{k} j_{k, z} c_{p, k}+\rho v_{z} c_{p}\right)+\frac{\epsilon}{\tau} \frac{\partial}{\partial z}\left(\lambda \frac{\partial T}{\partial z}\right) \\
& -\sum_{k} h_{k} \dot{w}_{k} W_{k}+\frac{S_{v}}{\gamma} \sum_{k} h_{k} K_{k}\left(\rho y_{k}-\rho_{b l} y_{k, b l}\right) \\
& -\frac{S_{v}}{\gamma} K_{T}\left(T-T_{b l}\right)
\end{aligned}
$$

Conservation of energy in the boundary layer:

$$
\begin{aligned}
\rho_{b l} c_{p, b l} \frac{\partial T_{b l}}{\partial t}= & -\frac{\partial T_{b l}}{\partial z} \sum_{k} j_{k, z, b l} c_{p, k, b l}+\frac{\epsilon}{\tau} \frac{\partial}{\partial z}\left(\lambda_{b l} \frac{\partial T_{b l}}{\partial z}\right) \\
& -\sum_{k} h_{k} \dot{w}_{k, b l} W_{k}-\frac{f_{a c t i v e} S_{v}}{1-\gamma} \sum_{k} h_{k} \dot{s}_{k, b l} W_{k} \\
& -\frac{S_{v}}{1-\gamma} \sum_{k} h_{k} K_{k}\left(\rho y_{k}-\rho_{b l} y_{k, b l}\right) \\
& +\frac{S_{v}}{1-\gamma} K_{T}\left(T-T_{b l}\right) \\
& -\frac{S_{v}}{1-\gamma} K_{T}\left(T_{b l}-T_{s}\right)
\end{aligned}
$$

Conservation of energy in the surface:

$$
\begin{aligned}
\rho_{s} c_{p, s} \frac{\partial T_{s}}{\partial t}= & \frac{\partial}{\partial z}\left(\lambda_{s} \frac{\partial T_{s}}{\partial z}\right)-\frac{\epsilon f_{\text {active }} S_{v}}{1-\epsilon} \sum_{k}^{N_{\text {surf }}} h_{k} \dot{s}_{k} W_{k} \\
& +\frac{\epsilon S_{v}}{1-\epsilon} K_{T}\left(T_{b l}-T_{s}\right) \\
& -\frac{\epsilon S_{v}}{1-\epsilon} \sigma\left(T_{s}^{4}-\frac{\kappa}{2} \int_{-\infty}^{\infty} T_{s}^{4}\left[z+z^{*}\right] e^{-\kappa\left|z^{*}\right|} d z^{*}\right)
\end{aligned}
$$

The energy balances of the surface and the boundary layer are given for completeness, but not solved during profile simulation. As mentioned above, the temperature of the gas in the boundary layer is assumed to be equilibrated with the surface temperature, and both temperatures are given by the pyrometer measurement. Finally, the estimation of the boundary layer thickness and volume fraction are defined:

$$
\begin{aligned}
\delta & =\frac{D_{\mathrm{O}_{2} m}}{K_{\mathrm{O}_{2}}} \\
r_{h} & =\frac{1}{2} \frac{4 \epsilon}{S_{v}} \\
\gamma & =1-\frac{\delta}{r_{h}}
\end{aligned}
$$

The simulations where performed using a FORTRAN code developed in house, which utilizes the API libraries of CHEMKIN [30]. A detailed description of the derivation of the reactor model, the numerical procedures used to solve the system of equations, and model validation against high-resolution spatial reactor profiles in catalytic carbon monoxide oxidation on $\mathrm{Pt}$ is subject of an upcoming paper by the authors. In this work the focus is on visualizing the capabilities of state-of-the-art microkinetic models considering transport phenomena against the recently available reactor profiles in $\mathrm{Pt}$ foam catalysts.

\subsection{Microkinetic Models}

Two state-of-the-art microkinetic models for $\mathrm{CH}_{4}$ oxidation on $\mathrm{Pt}$ are used in conjunction with the reactor model outlined above. The first reaction mechanism was adapted from Deutschmann and coworkers; this mechanism was developed for modeling methane $\mathrm{CPO}$ on a $\mathrm{Pt}$ gauze [31], and some of the rate parameters were subsequently updated to model the conversion of automotive exhaust gases on alumina-supported Pt [32]. Since the reactant mixture in this study does not contain nitrogen, reactions involving $\mathrm{NO}_{\mathrm{x}}$ were removed from the reaction mechanism, as were reactions regarding the decomposition of heavier molecular weight reactants that were not used in the present work. The resulting simplified mechanism consists of 23 reversible elementary reactions among 12 surface and 7 gas-phase species. The reaction mechanism is given in Tab. 4 in the Appendix and will be referred to in the following as Mechanism 1.

The second reaction mechanism was adapted from work of Vlachos and coworkers on methane partial oxidation, combustion, and reforming. The original rate coefficient parameters were taken from [33]; the reactions specific to synthesis gas formation were recently updated, [34], and these updates were included. Reactions involving oxygenates, such as methanol and formaldehyde, were removed from the mechanism. Preliminary calculations revealed that inclusion of these species was unnecessary, as the corresponding rates of production were negligible under partial oxidation conditions. Including these oxygenates also adversely affected the numerical stability of the simulations. The resulting simplified mechanism consists of 32 reversible elementary reactions amongst 13 surface and 7 gas-phase species. The reaction mechanism can be found in Tab. 5 in the Appendix and will be referred to as Mechanism 2. For both mechanisms, the desorption of radicals from the surface into the gas phase was neglected, and homogeneous chemistry in the gas phase was not included.

Additional catalyst key parameters for the reactor models are summarized in Tab. 1.

\section{Results and Discussion}

\subsection{Microkinetic Modeling Results Compared with Exper- imental Reactor Profiles}

With the aim of gaining mechanistic insight in the methane CPO, two chemical kinetic mechanisms have been used and are compared to the measured reactor profiles. Figs. 3 and 4 depict experimental and simulated reactor profiles measured at 2000 and $4000 \mathrm{mln} \mathrm{min}^{-1}$ gas feed at a $\mathrm{C} / \mathrm{O}$ ratio of 1.0. The exact gas feed composition is 
Table 2: Product selectivities of experimental and simulated reactor performance at catalyst bed end (axial position of 20 mm).

\begin{tabular}{|c|c|c|c|}
\hline Conversion $X[\%]$ or selectivity $S[\%]$ & Experiment & Mechanism 1 & Mechanism 2 \\
\hline$X_{\mathrm{CH}_{4}}^{@ 2000 \mathrm{mln} \min ^{-1}}$ & 63 & 33 & 51 \\
\hline$X_{\mathrm{CH}_{4}}^{@ 4000 \mathrm{mln} \min ^{-1}}$ & 59 & 41 & 56 \\
\hline$X_{\mathrm{O}_{2}}^{\mathrm{O}_{2}} 2000 \mathrm{mln} \mathrm{min}^{-1}$ & $>99$ & 99 & 99 \\
\hline$X_{\mathrm{O}_{2}}^{@} 4000 \mathrm{mln} \min ^{-1}$ & $>97$ & 98 & 97 \\
\hline$S_{\mathrm{H}_{2}}^{@ 2000 \mathrm{mln} \min ^{-1}}$ & 70 & 28 & 4 \\
\hline$S_{\mathrm{H}_{2}}^{@} 4000 \mathrm{mln} \min ^{-1}$ & 67 & 39 & 52 \\
\hline$S_{\mathrm{CO}}^{@ 2000 \mathrm{mln} \min ^{-1}}$ & 83 & 24 & $\approx 99$ \\
\hline$S_{\mathrm{CO}}^{@ 4000 \mathrm{mln} \min ^{-1}}$ & 90 & 55 & $\approx 99$ \\
\hline$S_{\mathrm{H}_{2} \mathrm{O}}^{@ 2000 \mathrm{mln} \min ^{-1}}$ & 30 & 72 & 59 \\
\hline$S_{\mathrm{H}_{2} \mathrm{O}}^{@} \mathrm{O} \operatorname{mln} \min ^{-1}$ & 33 & 61 & 48 \\
\hline$S_{\mathrm{CO}_{2} 2000 \mathrm{mln} \min ^{-1}}$ & 17 & 76 & $\approx 1$ \\
\hline$S_{\mathrm{CO}_{2} 4000 \mathrm{mln} \min ^{-1}}^{@}$ & 10 & 45 & $\approx 1$ \\
\hline
\end{tabular}

Table 1: Catalyst characterization.

$\begin{array}{ll}\text { support material } & \alpha-\mathrm{Al}_{2} \mathrm{O}_{3} \\ \text { pore density (manufacturer) } & 80 \mathrm{ppi} \\ \text { monolith dimensions (diameter/length) } & 16.2 / 20 \mathrm{~mm} \\ \text { catalyst mass }\left(\mathrm{Al}_{2} \mathrm{O}_{3}+\mathrm{Pt}\right) & 3.90 \mathrm{~g} \\ \text { Pt loading } & 1.09 \mathrm{wt} \% \\ \text { geometric surface area (from } \mu \text {-CT) } & 4650 \mathrm{~m}^{2} \mathrm{~m}^{3} \\ \text { Kr-BET surface area } & 0.159 \mathrm{~m}^{2} \mathrm{~g}^{-1} \\ \text { Pt surface area } & 0.015 \mathrm{~m}^{2} \mathrm{~g}^{-1} \\ \text { Pt dispersion } & 0.6 \% \\ \text { Solid foam volume (from } \mu \text {-CT) } & 1.00 \cdot 10^{-6} \mathrm{~m}^{3} \\ \text { Gas void volume (bulk }+ \text { b.l., from } \mu \text {-CT) } & 3.03 \cdot 10^{-6} \mathrm{~m}^{3} \\ \text { porosity (from } \mu \text {-CT) } & 0.7 \\ \text { tortuosity (from Ref. }[19]) & 1.7\end{array}$

given in the figure captions. Figs. 5 and 6 give the corresponding predicted surface mole fractions.

The experimental profiles are divided in two reaction zones. The first zone is characterized by rapid methane and oxygen conversion and is accompanied by heat production. The second zone is characterized by much slower methane and oxygen conversion and steam reforming. At $2000 \mathrm{mln}$ min flow rate $\mathrm{CH}_{4}$ steam reforming and water gas shift are coupled, yielding a flat CO profile. At $4000 \mathrm{mln} \mathrm{min}^{-1}$, when the catalyst temperature is higher, exothermic water gas shift is less pronounced. Both kinetic models show significant deviations in the predicted exit gas composition compared with the experimental reactor profiles. Only the $\mathrm{O}_{2}$ profile is, apart from the sudden change in slope, predicted by both mechanisms with quantitative accuracy. Methane conversion by Mechanism 1 and Mechanism 2 are predicted to be $33 \%$ and $51 \%$, respectively, whereas the experimentally observed conversion is $63 \%$. The main difference between the measured and predicted profiles concerns the extent of total oxidation. Mechanism 1 overpredicts the branching fraction towards total oxidation, indicated by the high predicted selectivity to $\mathrm{CO}_{2}$ at the expense of low selectivity to CO. Mechanism 2, in contrast, predicts the $\mathrm{CO}$ profile with quantitative accuracy. The $\mathrm{H}_{2}$ selectivity however is under-predicted by both mechanisms, and the selectivity to $\mathrm{CO}_{2}$ in Mechanism 2 amounts to almost zero. Mechanism 1 predicts water gas shift (i.e. CO $+\mathrm{H}_{2} \mathrm{O} \rightleftharpoons \mathrm{CO}_{2}+\mathrm{H}_{2}$ ), whereas Mechanism 2 shows no water gas shift. Generally speaking, Mechanism 2 does a better job of predicting the measured profiles under most conditions. However, under certain conditions - particularly high-pressure, fuel-rich experiments - Mechanism 1 was in better agreement with the experimental data.

Tab. 2 summarizes the product selectivities at the end of the catalyst section, i.e. at $20 \mathrm{~mm}$ axial position. At a gas feed rate of $\dot{V}_{\text {total }}=4000 \mathrm{mln} \mathrm{min}^{-1}$ the oxidation zone is stretched over the length of the entire catalyst bed. For the first $\approx 6 \mathrm{~mm}$, the profiles of $\mathrm{CH}_{4}$ and $\mathrm{O}_{2}$ are linear. After $6 \mathrm{~mm}$, the net rate of reactant conversion decreases abruptly, which is exhibited as a kink in the species profiles (see Fig. 3). The $\mathrm{H}_{2}$ and $\mathrm{CO}$ profiles diverge after this position, with higher $\mathrm{H}_{2}$ formation rate compared to CO. The total oxidation products, $\mathrm{H}_{2} \mathrm{O}$ and $\mathrm{CO}_{2}$, form a plateau. The linearity of the initial oxidation zone has - Been observed on Pt catalysts before [35, 36]. Neither the linearity in the first oxidation zone suggesting an apparent zeroth order kinetic nor the kink in the species profiles can be reproduced by the mechanisms.

It has been speculated that this apparent zeroth-order reaction kinetics could be attributed to a low active-site density due to blockage of the active sites by carbonaceous deposits [35]. The existence and impact of the carbonaceous deposits will be discussed in greater detail in Sections 4.2 and 4.3. With respect to the microkinetic models, neither Mechanism 1 nor Mechanism 2 includes reactions that would lead to the growth in heavier molecular weight carbonaceous species. Consequently, it should come as no surprise that neither mechanism is capable of reproducing features that might be attributable to more complex heterogeneous surface effects. Both mechanisms predict 
vacant $\mathrm{Pt}$ sites as the largest site fraction in the initial oxidation zone, which is to be expected, given the high temperatures in this region. The two mechanisms differ dramatically, however, with respect to the surface coverages of other adsorbed species (see Fig. 6). Mechanism 1 predicts that chemisorbed $\mathrm{CO}(\mathrm{s})$ is the next most abundant surface intermediate, and that the surface concentration of non-oxygenated carbon intermediates $-\mathrm{CH}_{3}(\mathrm{~s}), \mathrm{CH}_{2}(\mathrm{~s})$, $\mathrm{CH}(\mathrm{s})$, and $\mathrm{C}(\mathrm{s})$ - are orders of magnitude lower. Mechanism 2, in contrast, predicts that both $\mathrm{CH}(\mathrm{s})$ and $\mathrm{C}(\mathrm{s})$ will be present in large amounts, with $\mathrm{CO}(\mathrm{s})$ roughly oneto-two orders of magnitude lower. Perhaps significantly, Mechanism 2 predicts that methylidyne, $\mathrm{CH}(\mathrm{s})$, will become the most abundant surface intermediate (MASI) $\approx$ $3 \mathrm{~mm}$ prior to the kink. Given the large uncertainty in the rate parameters, the fact that the model predicts $\mathrm{CH}(\mathrm{s})$ as the MASI so close to the experimentally observed kink is quite encouraging. If one were to posit a sequence of nucleation and agglomeration reactions that involve the coupling of $\mathrm{CH}(\mathrm{s}), \mathrm{C}(\mathrm{s})$, and heavier molecular weight carbonaceous species, then it is conceivable that such a mechanism would be able to reproduce a kink or some similar discontinuity in the reaction rates due to carbon growth and site blockage. Development of such a mechanism, however, was beyond the scope of the paper.

As will be discussed in Section 4.3, the dispersion of $\mathrm{Pt}$ along the reactor length is no longer uniform. Consequently, the fraction of the surface area that is catalytically active will change with position: $f_{\text {active }}=f(z)$. The exact change in this coverage, however, was difficult to quantify, and so a constant value was assumed for the simulations. Were it possible to include both carbon growth and spatial gradients in the catalyst load, then we would expect the models to perform significantly better.

\subsection{Spatially Resolved Raman spectroscopy}

The hypothesis that the change in the shape of the $\mathrm{O}_{2}$ profiles was correlated with surface carbon blockage was inferred from experiments on a polycrystalline Pt foil that showed significant carbon deposition during methane $\mathrm{CPO}$ at $800{ }^{\circ} \mathrm{C}$ [38]. However the stagnation flow geometry of the applied reactor cell in that study cannot exclude transport limitation over the $\mathrm{Pt}$ foil. Therefore a low oxygen partial pressure above the surface and a correspondingly oxygen-deficient catalyst surface could be a reason for the observed formation of surface carbonaceous deposits. As mass transport is much more efficient in the $\mathrm{Pt}$ foam catalysts applied in this study [21] the foam catalyst was spectroscopically characterized in more detail to verify if the observation on the $\mathrm{Pt}$ foil can be transferred to the foam monolith catalysts. A catalyst stack was prepared, consisting of two half monoliths, both with a half centerline channel. The stack was catalytically tested analogous to the regular shaped catalyst foams. After $18 \mathrm{~h}$ under autothermal operation at a gas feed of $\mathrm{CH}_{4} / \mathrm{O}_{2} / \mathrm{Ar}$ $=592 / 296 / 1112 \mathrm{mln} \mathrm{min}^{-1}(\mathrm{C} / \mathrm{O}=1.0)$ the reaction was shut down quickly by sudden replacing of the reactive gas feed by pure Ar of $4000 \mathrm{mln} \min ^{-1}$ feed rate.

Fig. 7 depicts a reactor profile measured through the half shell monoliths. Qualitatively, the species profiles exhibit the same features as observed with the intact full foam monoliths. Similar zoning is observed with a zone of fast $\mathrm{CH}_{4}$ and $\mathrm{O}_{2}$ conversion and formation of $\mathrm{H}_{2}, \mathrm{CO}$, and $\mathrm{H}_{2} \mathrm{O} . \mathrm{CO}_{2}$ is again produced with low selectivity. The species profiles seem to be displaced by about 1-2 mm, and a rounded profile shape is observed both in the first millimeters and at the kink position. This spatial offset is probably due to a slight increase in the linear velocity through the foam due to the void created by the slice. Mixing between the local gas and the bypass gas could then explain the rounding of the profiles. The kink position was determined by linear fitting of the species profiles prior and after the kink position. The intercept (see Fig. 7) of the fitting lines is located around 5-6 mm axial position, which is in agreement with the kink position in the reactor profiles of the regular shaped foam monolith.

The catalyst stack was separated after the reaction test,
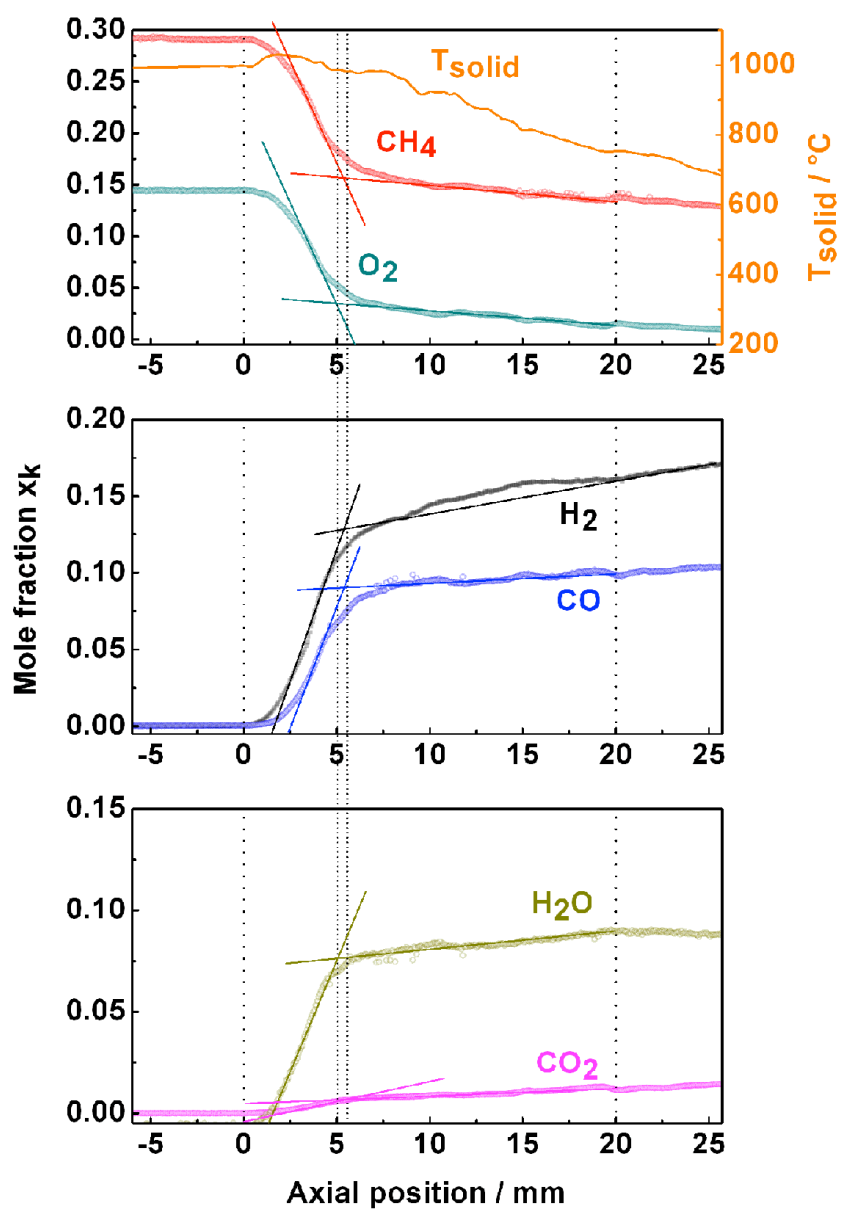

Figure 7: Mole fractions of $\mathrm{CH}_{4}$ and $\mathrm{O}_{2}$ with catalyst surface temperatures (top panel), mole fractions of $\mathrm{H}_{2}$ and $\mathrm{CO}$ (center panel), and mole fractions of $\mathrm{H}_{2} \mathrm{O}$ and $\mathrm{CO}_{2}$ (bottom panel). Reactor in autothermal operation with a gas feed of $\mathrm{CH}_{4} / \mathrm{O}_{2} / \mathrm{Ar}=$ $592 / 296 / 1112 \mathrm{mln} \mathrm{min}^{-1}(\mathrm{C} / \mathrm{O}=1.0)$. 

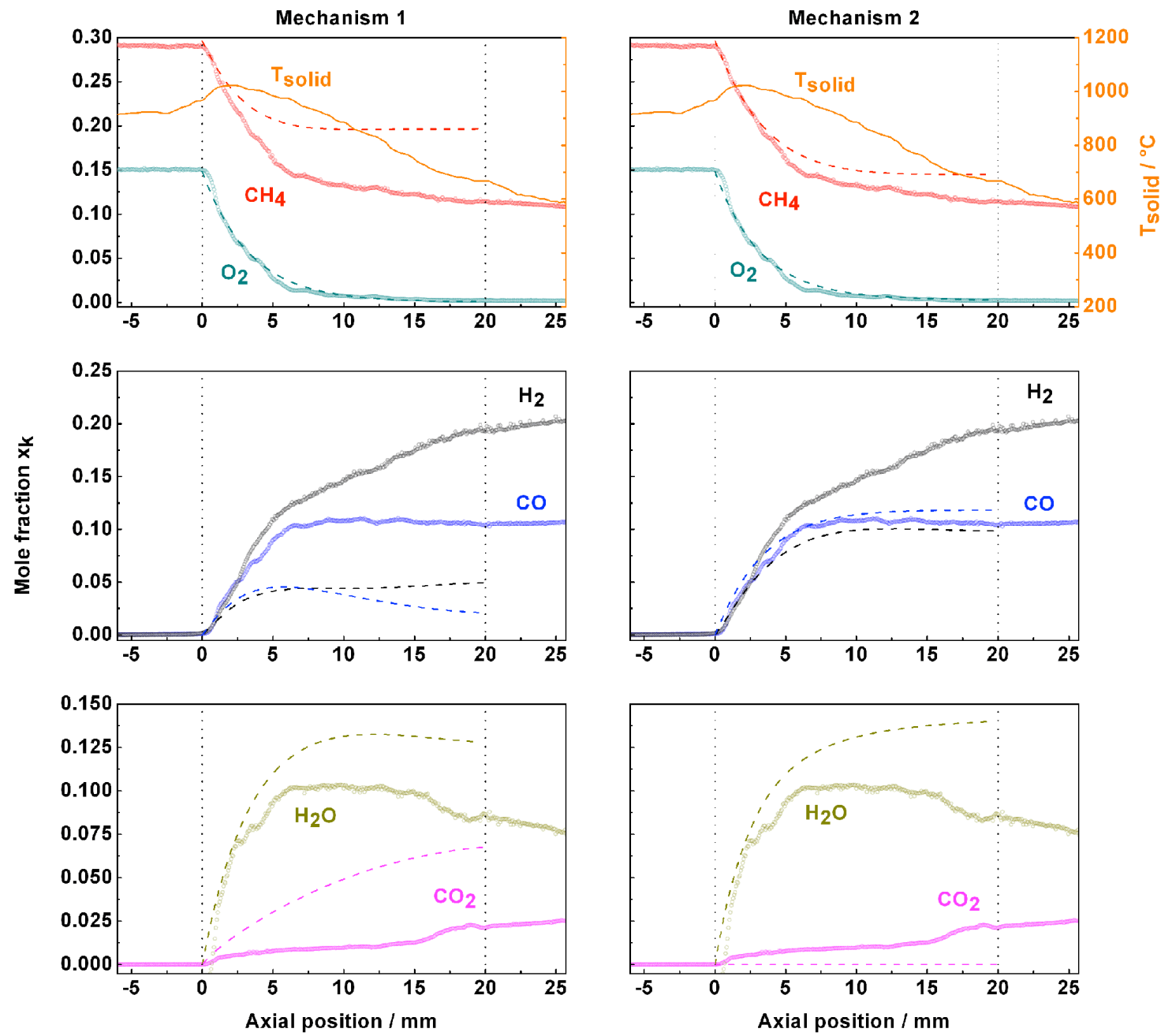

Figure 3: Mole fractions of $\mathrm{CH}_{4}$ and $\mathrm{O}_{2}$ with catalyst surface temperatures (top panels), mole fractions of $\mathrm{H}_{2}$ and $\mathrm{CO}$ (center panels), and mole fractions of $\mathrm{H}_{2} \mathrm{O}$ and $\mathrm{CO}_{2}$ (bottom panels) comparing prediction of the microkinetic models (dashed lines) of Mechanism 1 [31, 32, 37] (left panels) and Mechanism $2[33,34]$ (right panels) with experimental reactor profiles (symbols). Reactor in autothermal operation with a gas feed of $\mathrm{CH}_{4} / \mathrm{O}_{2} / \mathrm{Ar}=592 / 296 / 1112 \mathrm{mln} \mathrm{min}^{-1}(\mathrm{C} / \mathrm{O}=1.0)$ 

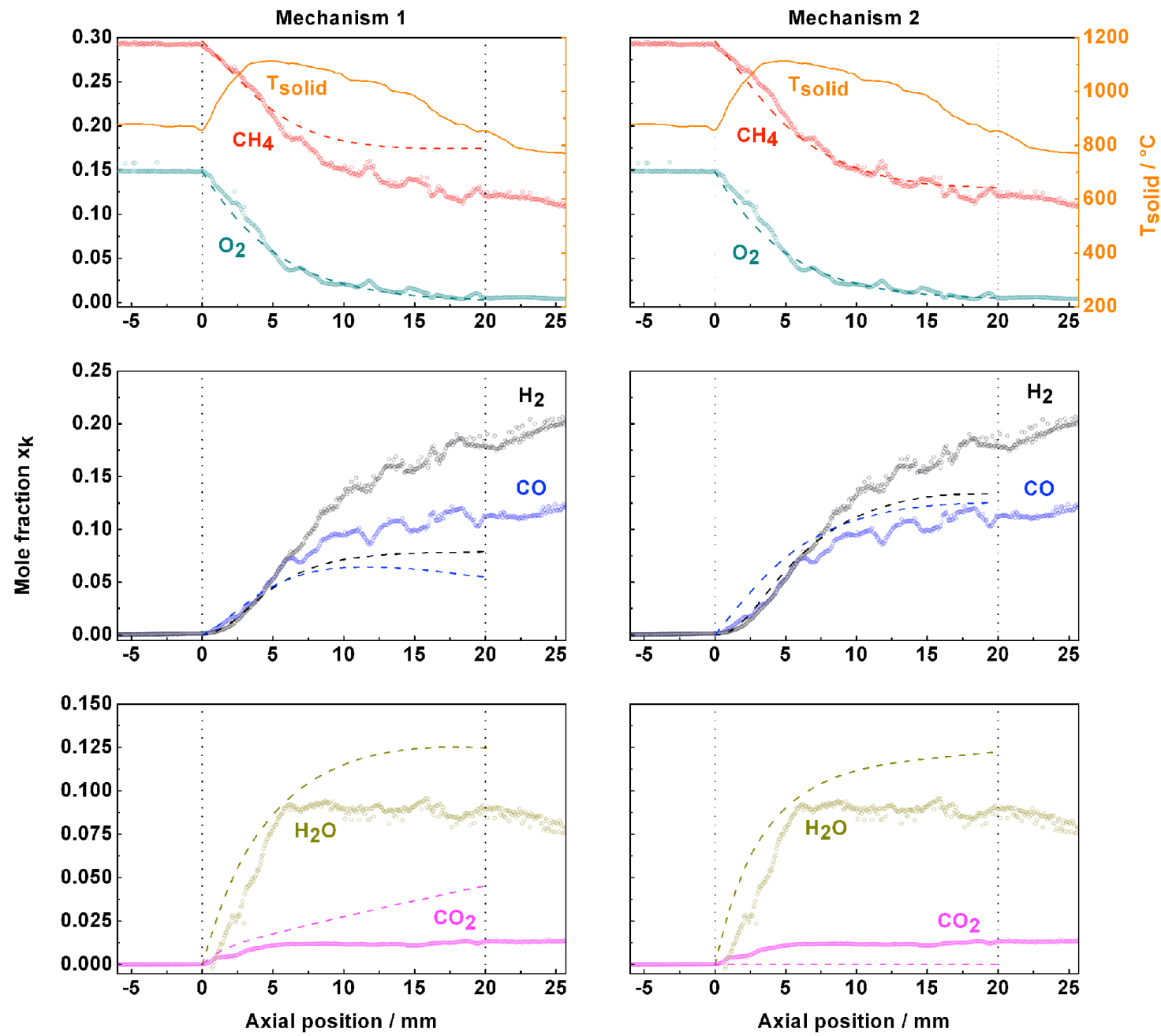

Figure 4: Mole fractions of $\mathrm{CH}_{4}$ and $\mathrm{O}_{2}$ with catalyst surface temperatures (top panels), mole fractions of $\mathrm{H}_{2}$ and $\mathrm{CO}$ (center panels), and mole fractions of $\mathrm{H}_{2} \mathrm{O}$ and $\mathrm{CO}_{2}$ (bottom panels) comparing prediction of the microkinetic models (dashed lines) of Mechanism 1 [31, 32, 37] (left panels) and Mechanism $2[33,34]$ (right panels) with experimental reactor profiles (symbols). Reactor in autothermal operation with a gas feed of $\mathrm{CH}_{4} / \mathrm{O}_{2} / \mathrm{Ar}=1184 / 592 / 2224 \mathrm{mln} \mathrm{min}^{-1}(\mathrm{C} / \mathrm{O}=1.0)$. 

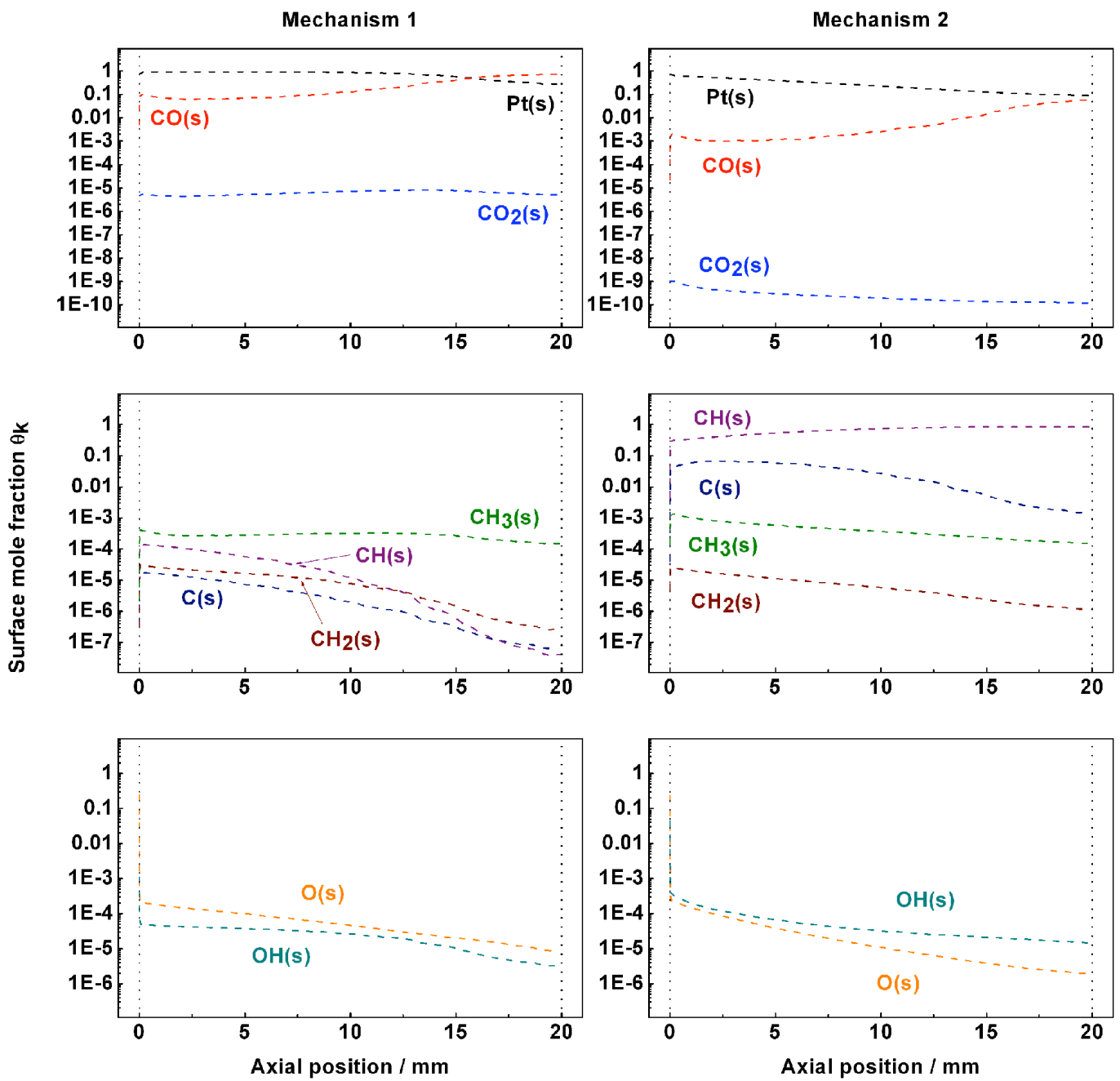

Figure 5: Surface mole fractions of $\mathrm{Pt}(\mathrm{s}), \mathrm{CO}(\mathrm{s})$, and $\mathrm{CO}_{2}(\mathrm{~s})$ (top panels), surface mole fractions of $\mathrm{C}(\mathrm{s}), \mathrm{CH}(\mathrm{s}), \mathrm{CH}_{2}(\mathrm{~s})$, and $\mathrm{CH}_{3}(\mathrm{center}$ panels), and surface mole fractions of $\mathrm{O}(\mathrm{s})$ and $\mathrm{OH}(\mathrm{s})$ (bottom panel) comparing the predictions of the microkinetic models (dashed lines) of Mechanism 1 [31, 32, 37] (left panels) and Mechanism 2 [33, 34]. Corresponding gas phase species and reaction conditions in Fig. 3. 

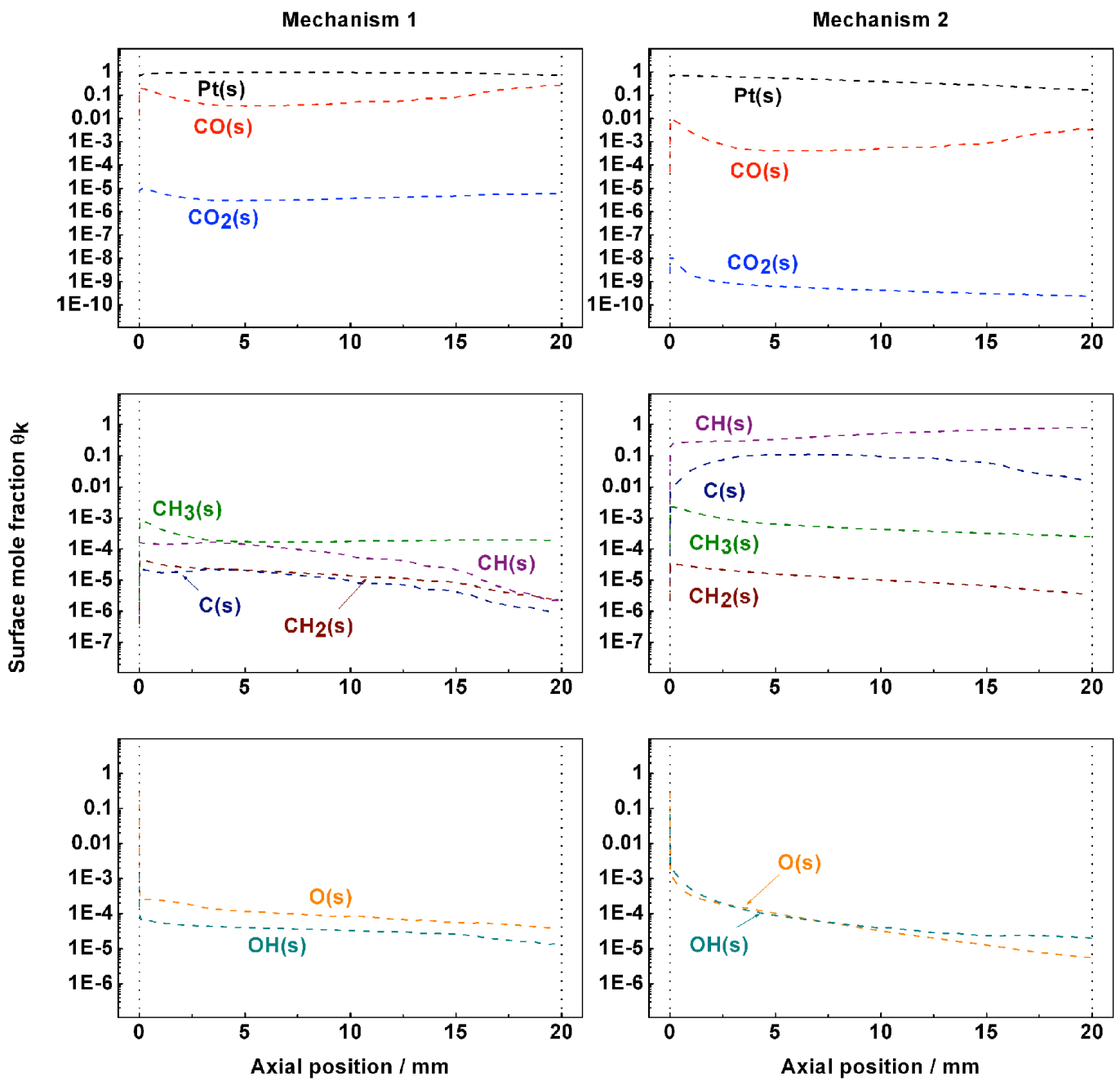

Figure 6: Surface mole fractions of $\mathrm{Pt}(\mathrm{s}), \mathrm{CO}(\mathrm{s})$, and $\mathrm{CO}_{2}(\mathrm{~s})$ (top panels), surface mole fractions of $\mathrm{C}(\mathrm{s}), \mathrm{CH}(\mathrm{s}), \mathrm{CH}_{2}(\mathrm{~s})$, and $\mathrm{CH}_{3}(\mathrm{center}$ panels), and surface mole fractions of $\mathrm{O}(\mathrm{s})$ and $\mathrm{OH}(\mathrm{s})$ (bottom panel) comparing the predictions of the microkinetic models (dashed lines) of Mechanism 1 [31, 32, 37] (left panels) and Mechanism 2 [33, 34]. Corresponding gas phase species and reaction conditions in Fig. 4. 


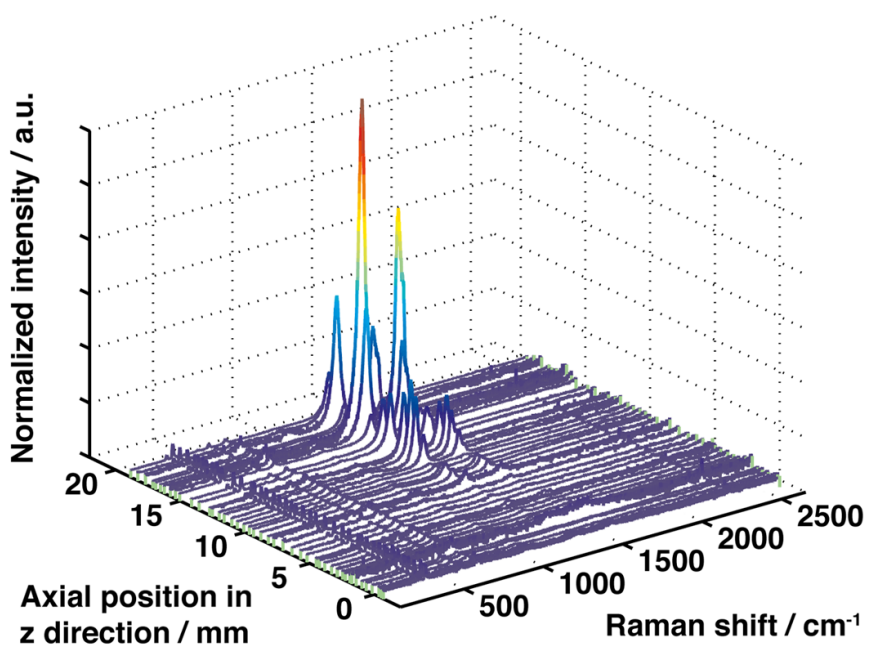

Figure 8: Detection of carbonaceous deposits by Raman microscopy after reaction test of two half monoliths. Axial position $z$ along the capillary channel centerline.

and Raman spectra were recorded along the centerline channel of both half monoliths. The obtained Raman spectra were normalized to the most intense Raman band of the corundum support, $420 \mathrm{~cm}^{-1}$. Fig. 8 shows the collected Raman spectra as a function of the axial position in the foam half channel of one half monolith. Within the first $5 \mathrm{~mm}$ of the catalyst the Raman spectra are dominated by a noisy background signal and the weak Raman peaks of the corundum support located at $382,420,578$, 649 , and $754 \mathrm{~cm}^{-1}[39,40]$.

At $\approx 5 \mathrm{~mm}$ axial position, which coincides with the sudden change in slope of all species profiles, two new bands at $\approx 1350$ and $\approx 1580 \mathrm{~cm}^{-1}$ appear. As the position increases, these two peaks dominate the background signal. These two bands are characteristic for defective carbon materials such as coke or soot. The maxima are referred to as $\mathrm{D}$ band and $\mathrm{G}$ band. The $\mathrm{G}$ band or 'graphite peak' is assigned to the vibrational mode of in-plane bond stretching motion of $\mathrm{sp}^{2}$-hybridized carbon atoms with $\mathrm{E}_{2 \mathrm{~g}} \mathrm{sym}-$ metry. It is characteristic for an ideal graphitic lattice [41]. The D band or 'defect peak' is a superposition of up to four peaks characteristic for disordered graphite [42]. The relative intensity and broadening of the D band compared to the G peak intensity is a measure of the structural disorder of the carbon material. If the carbon bands are broadened and overlapping the D band can be separated, following the method of Sadezky et al. [42]. The so-called D1 peak, i.e. the major peak in the $\mathrm{D}$ band, is associated with the $A_{1 g}$ breathing mode of a graphitic lattice and is assigned to carbon atoms located adjacent to lattice disturbances such as graphene layer edges [42-45]. The D1 full width at half maximum has a nearly linear negative correlation with the abundance of elemental carbon in a carbonaceous material $[46,47]$. Three other peaks are de- scribed to contribute to the D band shape and intensity. The D3 located at $\approx 1500 \mathrm{~cm}^{-1}$ originates from amorphous, molecular carbon species $[42,48-50]$. The $\mathrm{D} 4$ peak located at $\approx 1200 \mathrm{~cm}^{-1}$ is assigned to $\mathrm{sp}^{2}-\mathrm{sp}^{3}$ bonds or $\mathrm{C}-\mathrm{C}$ or $\mathrm{C}=\mathrm{C}$ stretching vibrations of polyene-like structures with $\mathrm{A}_{1 \mathrm{~g}}$ symmetry $[42,48,49]$. The D2 peak also exhibits a shoulder at $\approx 1620 \mathrm{~cm}^{-1}$. It is assigned to a lattice vibration analogous to the $\mathrm{G}$ band but involving vibrations of surface graphene layers [42, 45].

The carbon bands observed in this study are non-overlapping, which is consistent with a structured carbon material. The D3 band intensity, which is a good measure for the amorphization of a carbon material is absent in the apparent dataset. The $\mathrm{G}$ band shows a shoulder centered at $1617 \mathrm{~cm}^{-1}$ indicating a fraction of graphene-like fragments on the catalyst. In summary, although a quantitative interpretation of the Raman intensities is difficult, it can be concluded that carbonaceous deposits are formed in the reaction zone following the kink position, and that their relative abundance increases towards the end of the catalyst. Additionally, the absence of gas-phase oxygen favors the formation of carbonaceous deposits. In agreement with our earlier study on a polycrystalline Pt foil [38], the carbon species exhibit a graphitic nature that is resistant to steam reforming.

\subsection{Spatially Resolved SEM}

The foam half monoliths were additionally investigated using electron microscopy to characterize the catalyst surface morphology. The SEM study was done prior to and after the reaction to compare between the as-prepared catalyst with the used catalyst.

The first noteworthy observation is a strong redistribution/dispersion of the metal particles after the reaction test. Fig. 9A and 9B represent typical $\mathrm{Pt}$ agglomerates as they were present over the whole half monolith after preparation. The preparation method resulted in a rather inhomogeneous metal distribution, with patches of high metal particle density next to bare positions. After the reaction test the $\mathrm{Pt}$ agglomerates disappeared, and roughened corundum crystallites (Fig. 9C) remained. Higher magnification, as depicted in Fig. 9D, shows that although some Pt is still present at the original position, the particle size has decreased considerably and a lot of $\mathrm{Pt}$ is transported away. Reviewing the literature, it is speculated that the loss of $\mathrm{Pt}$ metal is due either to transport as volatile $\mathrm{PtO}_{2}$ in the presence of oxygen [14, 51-53], or by catalytic restructuring proceeded by the formation and decomposition of short-lived radical species that interact with the Pt particles $[14,54]$.Three different sections could be identified in the used half monolith, which are represented by the electron micrographs of Fig. 11. Fig. 11A presents a composite image of the entire half monolith; note that the reactor inlet, corresponding to $\mathrm{z}=0$, is at the bottom of the image. Electron micrographs we recorded along the centerline channel. After the reaction test no large agglomerates of $\mathrm{Pt}$ could be found. Up to an axial 

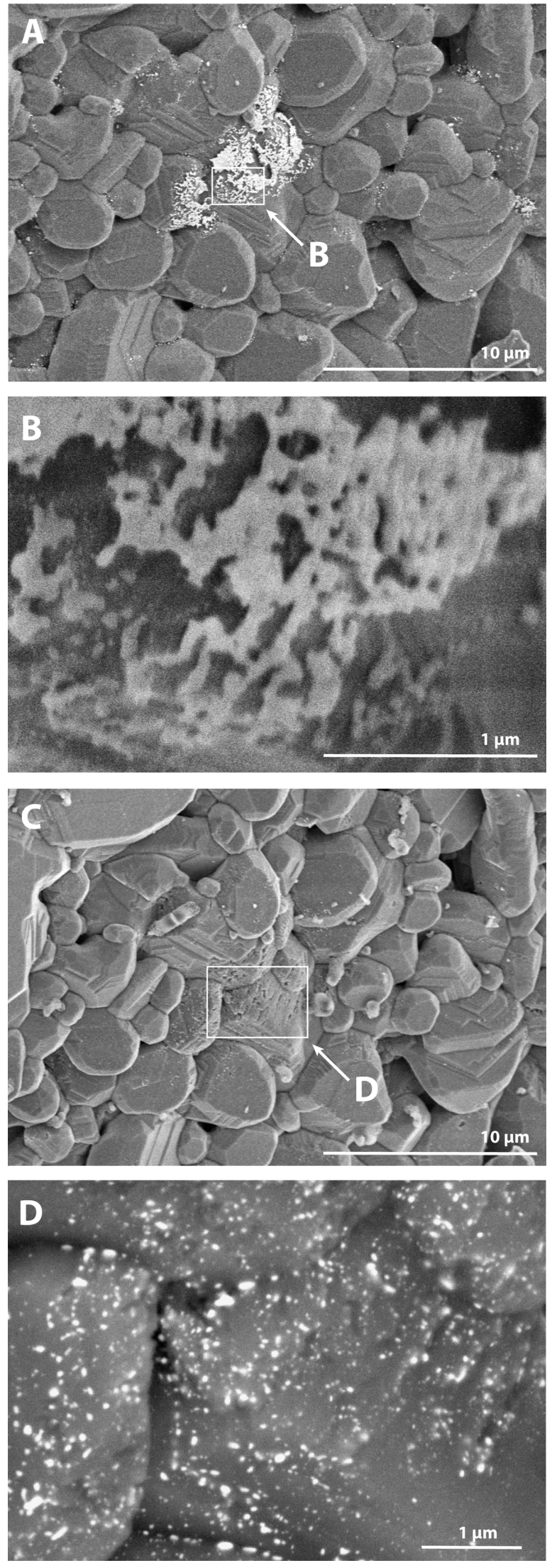

Figure 9: Electron micrographs comparing the as prepared Pt coated foam monolith with the monolith after reaction test at an axial position of about $4 \mathrm{~mm}$. A: SE image (HV, $5 \mathrm{kV})$ as prepared. B: SE image $(\mathrm{HV}, 1 \mathrm{kV})$ as prepared. C: SE image $(\mathrm{HV}, 5 \mathrm{kV})$ after reaction test. D: BSE image (Low vacuum $\left(60 \mathrm{~Pa} \mathrm{H}_{2} \mathrm{O}\right), 15 \mathrm{kV}$ ) after reaction test.

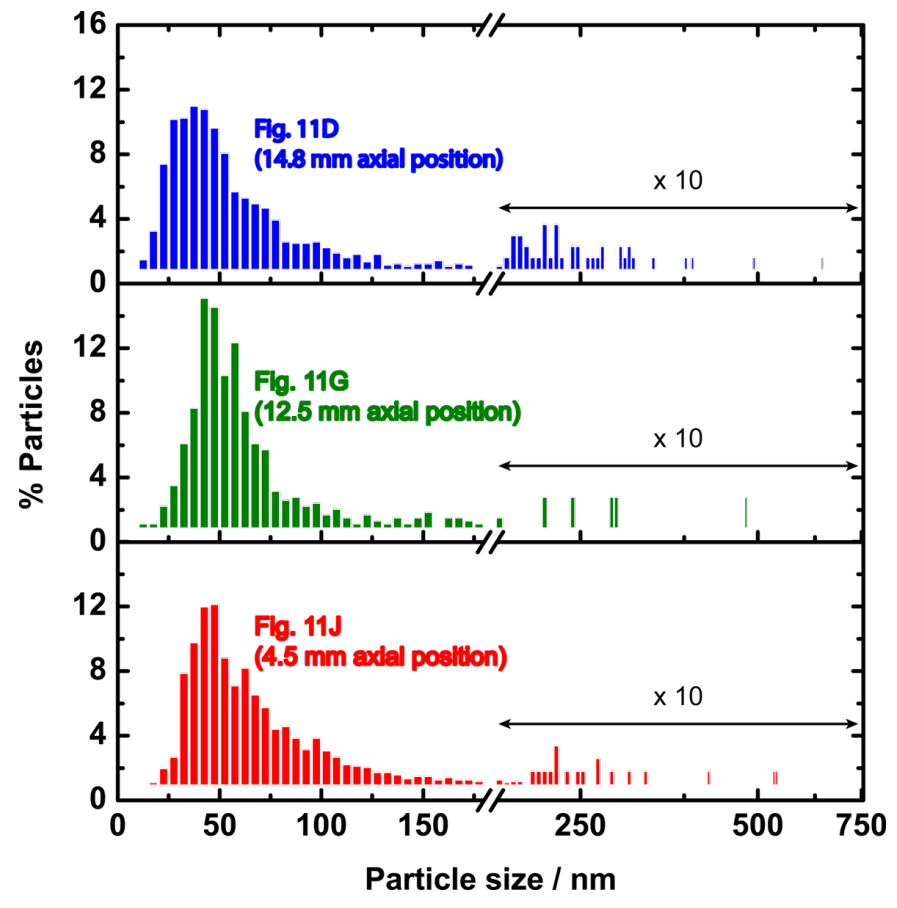

Figure 10: Plot of particle size distributions for Fig. 11D, 11G, and $11 \mathrm{~J}$ with a bin width of $5 \mathrm{~nm}$.

position of $\approx 5 \mathrm{~mm}$ the catalyst material was found to be clean, with only small Pt particles covering the corundum crystallites (Fig. 11H, 11I, and 11J). Filament-like carbon species are found throughout the intermediate zone, corresponding to the kink position at $\approx 6 \mathrm{~mm}$ and continuing up to $\approx 15 \mathrm{~mm}$ (Fig. 11E). Increased magnification reveals that the carbon filaments are directly attached to Pt particles (indicated by arrows in Fig. 11F). The final section corresponds to the last $\approx 5 \mathrm{~mm}$ of the catalyst monolith. Within this section, the carbonaceous deposits have agglomerated into roundish particles that cover the entire support surface. The sharp edges of the corundum crystallites as observed in the oxygen rich catalyst section are blurry and are barely visible due to the carbon encapsulation on top. The carbon spheres exhibit an eggshell structure enclosing $\mathrm{Pt}$ particles (Fig. 11C arrows).

An other interesting finding regards the $\mathrm{Pt}$ particle size. The overall integral breadth-based volume weighted mean Pt crystallite size was determined on a series of seven powdered catalyst monoliths coated with a nominal Pt loading of $1 \mathrm{wt} \%$ and amounts to $46 \pm 8 \mathrm{~nm}$ (see Tab. 3 ). The particle size distributions for the BSE images in Fig. 11D, 11G, and 11J are given in Fig. 10. In all three images the most abundant Pt particle diameter is roughly $45 \mathrm{~nm}$ independent of the axial position. A closer inspection, however, yields some interesting differences. First, the number of particles smaller than $35 \mathrm{~nm}$ increases along the length of the reactor. Second the number of particles greater than $150 \mathrm{~nm}$ is largest at the end of the reactor. Taken together, the SEM and XRD results confirm that both the particle size distribution and the total Pt loading have 
Table 3: Integral breadth-based volume weighted mean Pt crystallite size of powdered foam monoliths with a nominal Pt loading of $1 \mathrm{wt} \%$. $\mathrm{XRD}$ analysis after reaction tests.

\begin{tabular}{llll}
\hline ID & $\mathrm{a}[\ddot{A}]$ & $\mathrm{L} \mathrm{Vol-IB}[\mathrm{nm}]$ & $\mathrm{W}_{\mathrm{Pt}}[\%]$ \\
\hline$\# 10253$ & $3.92455(9)$ & $42(2)$ & 1.1 \\
$\# 10254$ & $3.92731(8)$ & $50(3)$ & 1.1 \\
$\# 12357$ & $3.92558(7)$ & $60(4)$ & 1.0 \\
$\# 12358$ & $3.92618(8)$ & $46(10)$ & 1.1 \\
$\# 12359$ & $3.92483(14)$ & $30(2)$ & 1.1 \\
$\# 12360$ & $3.92760(9)$ & $49(3)$ & 1.1 \\
$\# 10774$ & $3.92700(10)$ & $44(3)$ & 0.9
\end{tabular}

been changed by the reaction, and both properties are now functions of position, as seen in Figs. 11D, 11G, and 11J. Although neither the mechanism nor the rate of the catalyst transport can be determined at this time, it is clear nonetheless, that the $\mathrm{Pt}$ particles are redistributed prior to and/or during operation. $\mathrm{Pt}$ is transported from the front of the foam support - where the temperatures are highest - to the cooler, post-oxidation zone at the rear of the foam.

\section{Conclusion}

Spatially resolved high-resolution reactor profiles of species concentrations and catalyst surface temperature in autothermal methane CPO on Pt are presented. The measured profiles exhibit a two-zone structure. In the first zone, the rate of reactant conversion is fast and linear. In the second zone, the reaction rates are considerably slower, and the sharp decrease in net rates results in a kink in the species profiles. Post-reaction characterization of the catalyst by Raman spectroscopy and electron microscopy revealed that the $\mathrm{Pt}$ distribution changed when compared to the freshly prepared monolith. Characterization of the foam prior to reaction revealed islands of $\mathrm{Pt}$ particle agglomerates, but after several hours on stream, these Pt islands were re-dispersed. In the front of the foam where oxidation rates are highest, the large Pt agglomerates have disappeared, and only small $\mathrm{Pt}$ particles remain. In the post-oxidation zone where $\mathrm{O}_{2}$ partial pressure is lowest, the catalyst surface is enriched by larger spherical Pt particles covered with carbon deposits. These results clearly demonstrate that $\mathrm{Pt}$ is transported during operation from the hot catalyst front to the catalyst back. The kink position is correlated with the formation of carbonaceous deposits. The morphology of the carbon material changes from filament-like to a mixture of thickened filaments and large roundish agglomerates. Towards the end of the reactor, the $\mathrm{Pt}$ particles are embedded in the carbon material.

The measured profiles are compared with predicted profiles from a pseudo-2D heterogeneous reactor model that couples heat and mass transport limitations with detailed chemical kinetics. Two state-of-the-art microkinetic models taken from the literature are used: Mechanism 1 (de- veloped by Deutschmann and coworkers [31, 32, 37]) and Mechanism 2 (developed by Vlachos and coworkers [33, 34]). Although the model profiles are correct with respect to $\mathrm{O}_{2}$, the product profiles differ considerably. Mechanism 1 underpredicts methane conversion and overpredicts the branching fraction towards total oxidation. Mechanism 2 is in better agreement with the measured profiles, but it consistently underpredicts the rate of water gas shift. Although both models predict a high concentration of vacant sites in the initial oxidation zone, the two models differ significantly in their prediction of the surface coverages. Mechanism 1 predicts that $\mathrm{CO}(\mathrm{s})$ is the next most abundant surface species, whereas Mechanism 2 predicts high coverages of $\mathrm{CH}(\mathrm{s})$ and, to a lesser extent, $\mathrm{C}(\mathrm{s})$. Since neither mechanism includes a submechanism for carbon growth, it is not surprising that the simulations fail to predict the kink in the measured profiles. Nonetheless, the transition from a largely vacant surface to a surface covered with $\mathrm{CH}(\mathrm{s})$ predicted by Mechanism 2 coincides remarkably well with the kink position and formation of carbonaceous deposits. The disparities between the measured and predicted profiles indicate the need for further work in chemical kinetic mechanism development. The reactions that lead to the formation and agglomeration of carbonaceous species in low- $\mathrm{O}_{2}$ environments is critical.

\section{Acknowledgements}

All authors thank the German Research Foundation for funding the Emmy-Noether-Junior-Research-Group "High Temperature Catalysis". Further support was provided by the German Federal Ministry of Education and Research within the framework of the Excellence Cluster "Unifying Concepts in Catalysis". CFG gratefully acknowledges the financial support from the Alexander von Humboldt foundation.

The authors explicitly thank A. Fischer from Technische Universität Berlin for krypton BET measurements, I. Manke and A. Hilger from Helmholz-Zentrum Berlin for the $\mu$-CT measurements, and S. Wrabetz and F. Girgsdies from the Fritz Haber Institute of the Max Planck Society for validating the $\mathrm{H}_{2}$ chemisorption measurements by CO chemisorption in a microcalorimetric experiment and for determining the Pt crystallite size by XRD respectively. 

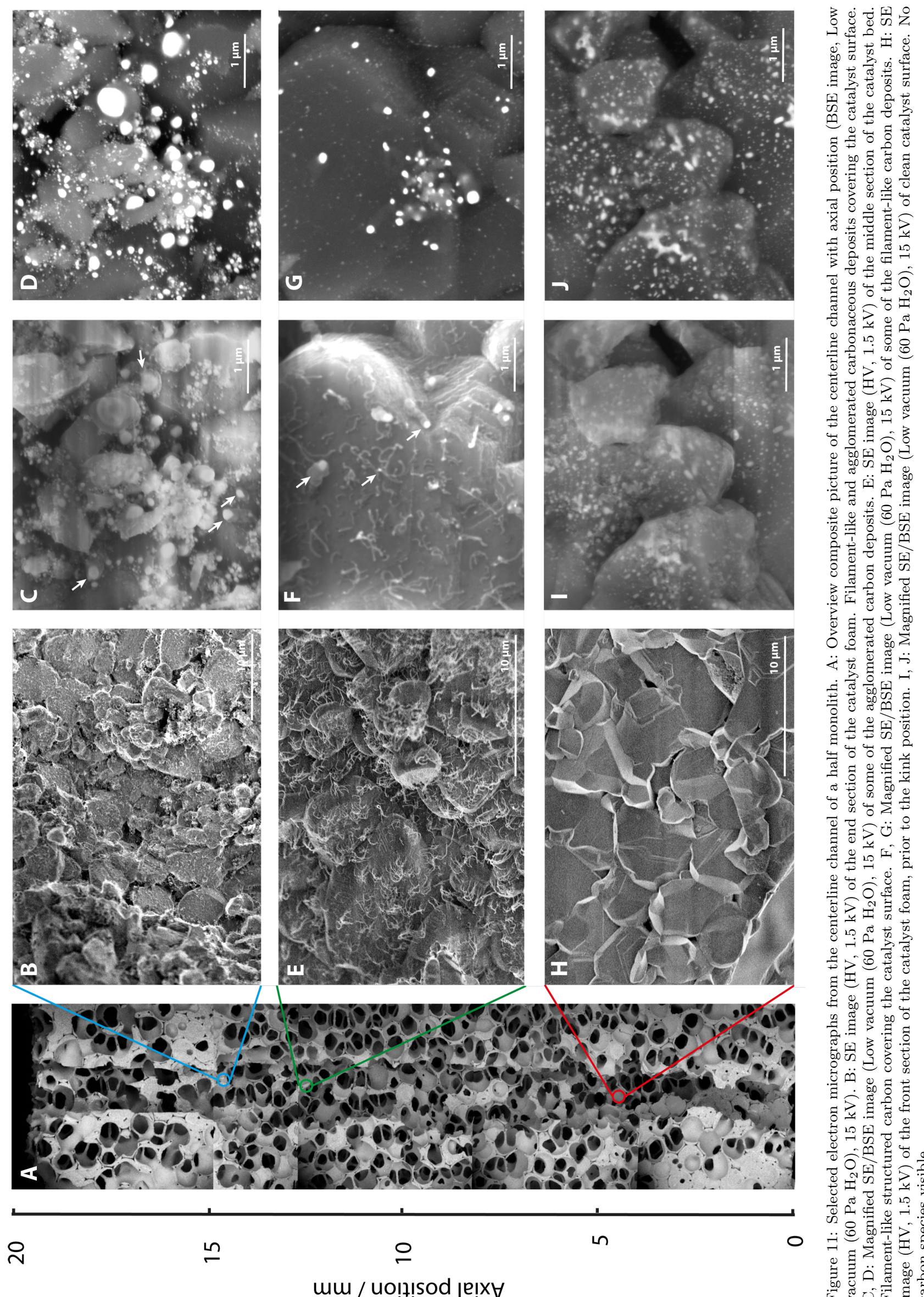

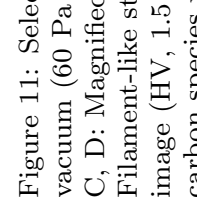


[1] J. R. Rostrup-Nielsen, Catalytic Steam Reforming, Vol. 5, Springer-Verlag Berlin Heidelberg New York, 1984, Ch. Catalytic Steam Reforming, pp. 1-117.

[2] D. A. Hickman, L. D. Schmidt, Production of Syngas by Direct Catalytic Oxidation of Methane, Science 259 (5093) (1993) 343346. doi:10.1126/science.259.5093.343.

[3] D. A. Hickman, L. D. Schmidt, Steps in $\mathrm{CH}_{4}$ Oxidation on Pt and Rh Surfaces: High-Temperature Reactor Simulations, AIChE J. 39 (7) (1993) 1164-1177. doi:10.1002/aic.690390708.

[4] D. A. Hickman, E. A. Haupfear, L. D. Schmidt, Synthesis gas formation by direct oxidation of methane over Rh monoliths, Catal. Lett. 17 (3-4) (1993) 223-237. doi:10.1007/BF00766145.

[5] D. A. Hickman, L. D. Schmidt, Synthesis Gas Formation by Direct Oxidation of Methane over Monoliths, ACS Symp. Ser. 523 (1993) 416-426. doi:10.1021/bk-1993-0523.ch032.

[6] M. Prettre, C. Eichner, M. Perrin, The catalytic oxidation of methane to carbon monoxide and hydrogen, Trans. Faraday Soc. 42 (1946) 335-339. doi:10.1039/TF946420335b.

[7] A. P. E. York, T.-c. Xiao, M. L. H. Green, J. B. Claridge, Methane Oxyforming for Synthesis Gas Production, Catal. Rev. - Sci. Eng. 47 (4) (2007) 511-560. doi:10.1080/01614940701583315.

[8] P. D. F. Vernon, M. L. H. Green, A. K. Cheetham, A. T. Ashcroft, Partial oxidation of methane to synthesis gas, Catal. Lett. 6 (2) (1990) 181-186. doi:10.1007/BF00774718.

[9] D. Dissanayake, M. P. Rosynek, K. C. C. Kharas, J. H Lunsford, Partial oxidation of methane to carbon monoxide and hydrogen over a Ni/Al2O3 catalyst, J. Catal. 132 (1) (1991) 117-127. doi:10.1016/0021-9517(91)90252-Y.

[10] O. V. Buyevskaya, D. Wolf, M. Baerns, Rhodium-catalyzed partial oxidation of methane to $\mathrm{CO}$ and $\mathrm{H}_{2}$. Transient studies on its mechanism, Catal. Lett. 29 (1-2) (1994) 249-260. doi:10.1007/BF00814271.

[11] O. V. Buyevskaya, D. Wolf, M. Baerns, Primary reaction steps and active surface sites in the rhodium-catalyzed partial oxidation of methane to $\mathrm{CO}$ and $\mathrm{H}_{2}$, Catal. Lett. 38 (1-2) (1996) 81-88. doi:10.1007/BF00806904.

[12] K. Walter, O. V. Buyevskaya, D. Wolf, M. Baerns, Rhodiumcatalyzed partial oxidation of methane to $\mathrm{CO}$ and $\mathrm{H}_{2}$. In situ DRIFTS studies on surface intermediates, Catal. Lett. 29 (1-2) (1994) 261-270. doi:10.1007/BF00814272.

[13] D. A. Hickman, L. D. Schmidt, Synthesis gas formation by direct oxidation of methane over Pt monoliths, J. Catal. 138 (1) (1992) 267-282. doi:10.1016/0021-9517(92)90022-A.

[14] K. Heitnes Hofstad, T. Sperle, O. A. Rokstad, A. Holmen, Partial oxidation of methane to synthesis gas over a Pt/10\% Rh gauze, Catal. Lett. 45 (1-2) (1997) 97-105. doi:10.1023/A:1019030604516.

[15] K. Heitnes Hofstad, O. A. Rokstad, A. Holmen, Partial oxidation of methane over platinum metal gauze, Catal. Lett. 36 (1-2) (1996) 25-30. doi:10.1007/BF00807201.

[16] R. Horn, N. J. Degenstein, K. A. Williams, L. D. Schmidt, Spatial and temporal profiles in millisecond partial oxidation processes, Catal. Lett. 110 (3-4) (2006) 169-178. doi:10.1007/s10562-006-0117-8.

[17] R. Horn, K. A. Williams, N. J. Degenstein, A. Bitsch-Larsen, D. Dalle Nogare, S. A. Tupy, L. D. Schmidt, Methane catalytic partial oxidation on autothermal $\mathrm{Rh}$ and $\mathrm{Pt}$ foam catalysts: Oxidation and reforming zones, transport effects, and approach to thermodynamic equilibrium, J. Catal. 249 (2) (2007) 380393. doi:10.1016/j.jcat.2007.05.011.

[18] A. Bitsch-Larsen, R. Horn, L. D. Schmidt, Catalytic partial oxidation of methane on rhodium and platinum: Spatial profiles at elevated pressure, Appl. Catal., A 348 (2) (2008) 165-172. doi:10.1016/j.apcata.2008.06.036.

[19] D. Dalle Nogare, N. J. Degenstein, R. Horn, P. Canu, L. D. Schmidt, Modeling spatially resolved profiles of methane partial oxidation on a Rh foam catalyst with detailed chemistry, J. Catal. 258 (1) (2008) 131-142. doi:10.1016/j.jcat.2008.06.006.

[20] D. Dalle Nogare, N. J. Degenstein, R. Horn, P. Canu, L. D. Schmidt, Modeling Spatially Resolved Data of Methane Cat-

\section{Nomenclature}

$p$

$R$

$\bar{W} \equiv \sum_{k} x_{k} W_{k}$

$y_{k}$

$x_{k}=\frac{1}{\sum_{j} \frac{y_{j}}{W_{j}}} \frac{y_{k}}{W_{k}}$

$D_{k m}$

$v_{z}$

$\mu$

$j_{k}=-\rho D_{k m} \frac{\epsilon}{\tau} \frac{W_{k}}{\bar{W}} \frac{\partial x_{k}}{\partial z}$

$W_{k}$

$\dot{w}_{k}$

$\dot{s}_{k}$

$\tau$

$\theta_{k}$

$\Gamma$

$\sigma_{k}$

$h_{k}$

$c_{p}$

$\lambda$

$K_{k}=S_{h} l^{-1} D_{k m}$

$K_{T}=N_{u} l^{-1} \lambda$

$z$

$S_{v}($ from $\mu-\mathrm{CT})$

$A($ from $\mu$-CT)

$l=\frac{4 \epsilon}{S_{v}}$

$\delta=\frac{D_{\mathrm{O}_{2} m}}{K_{\mathrm{O}_{2}}}$

$\gamma=\frac{V_{\text {vod }}-V_{b l}}{V_{\text {void }}}$

$\epsilon \equiv \frac{V_{\text {void }}}{V_{\text {total }}}$

$t$

$\mathrm{C} / \mathrm{O}$ ratio $=\frac{\dot{V}_{\mathrm{CH}_{4}}}{2 \dot{V}_{\mathrm{O}_{2}}}$

$\kappa$
$\overrightarrow{e_{z}}$

$f_{\text {active }}$

$\dot{V}_{k}$

\section{Dimensionless numbers}

$R_{e}$

$S_{c}$

$P_{r}$

\section{Transport correlations}

$$
\begin{aligned}
& S_{h} \quad=0.045 R_{e}^{1 / 2} S_{c}^{1 / 3} \\
& N_{u} \quad=0.045 R_{e}^{1 / 2} P_{r}^{1 / 3}
\end{aligned}
$$

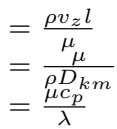

Mass density, $\mathrm{kg} \mathrm{m}^{-3}$

pressure, $\mathrm{Pa}$

Ideal gas constant,

8.3144621 $\mathrm{J} \mathrm{K}^{-1} \mathrm{~mol}^{-1}$

Temperature, K

Average molecular weight, $\mathrm{kg} \mathrm{kmol}^{-1}$

Mass fraction for species $k, \mathrm{~kg}_{k} \mathrm{~kg}_{\text {tot }}^{-1}$

Mole fraction for species $k, \mathrm{~mol}_{k} \mathrm{~mol}_{\text {tot }}^{-1}$

Mixture-average diffusion coefficient for species $k, \mathrm{~m}^{2} \mathrm{~s}^{-1}$

Velocity, $\mathrm{m} \mathrm{s}^{-1}$

Average dynamic viscosity, $\mathrm{kg} \mathrm{m}^{-1} \mathrm{~s}^{-1}$

Flux of species $k$ due to molecular diffusion, $\mathrm{kg} \mathrm{m}^{-2} \mathrm{~s}^{-1}$

Molecular mass of species $k, \mathrm{~kg} \mathrm{kmol}^{-1}$ Molar rate of production per unit volume of species $k$ by homogeneous chemistry, mol m${ }^{-3} \mathrm{~s}^{-1}$

Molar rate of production per unit area for species $k$ due to surface chemistry, mol m${ }^{-2} \mathrm{~s}^{-1}$

Tortuosity of the foam, $\mathrm{m} \mathrm{m}^{-1}$

Site fraction of species $k$ on Pt surface, mol mol ${ }^{-1}$

Surface site density, $\mathrm{mol} \mathrm{m}^{-2}$

Number of sites occupied by $k$, $\mathrm{mol} \mathrm{mol}{ }^{-1}$

Specific enthalpy, $\mathrm{J} \mathrm{kg}^{-1}$

Average heat capacity, $\mathrm{J} \mathrm{K}^{-1} \mathrm{~kg}^{-1}$

Average thermal conductivity,

$\mathrm{W} \mathrm{m} \mathrm{m}^{-1} \mathrm{~K}^{-1}$

Mass transfer coefficient, $\mathrm{m} \mathrm{s}^{-1}$

Heat transfer coefficient, $\mathrm{W} \mathrm{m}{ }^{-2} \mathrm{~K}^{-1}$

Axial coordinate, $m$

Geometric foam surface area to total gas-phase volume, $\mathrm{m}^{-1}$

Geometric surface area of catalyst foam, $\mathrm{m}^{2}$

Characteristic length, $\mathrm{m}$

Boundary layer thickness, $m$

Volume fraction of bulk gas, $\mathrm{m}^{3} \mathrm{~m}^{-3}$

Foam porosity, with

$V_{\text {total }}=V_{\text {void }}+V_{\text {solid }}$

Time, $\mathrm{s}$

Ratio between atomic carbon

and oxygen in gas feed

Extinction coefficient, $2550 \mathrm{~m}^{-1}$ [19]

Unit vector

Ratio of active metal surface area

(from $\mathrm{H}_{2}$ chemisorption) and support surface area (from Kr-BET), $\mathrm{m}^{2} \mathrm{~m}^{-2}$

Volumetric flow rate of species $k$, $\mathrm{ml} \mathrm{min}^{-1}$ 
alytic Partial Oxidation on Rh Foam Catalyst at Different Inlet Compositions and Flow Rates, J. Catal. 277 (2) (2011) 134-148. doi:10.1016/j.jcat.2010.10.020.

[21] O. Korup, S. Mavlyankariev, M. Geske, C. F. Goldsmith, R. Horn, Measurement and analysis of spatial reactor profiles in high temperature catalysis research, Chem. Eng. Process. 50 (10) (2011) 998-1009. doi:10.1016/j.cep.2011.05.024.

[22] F. Garciá Moreno, M. Fromme, J. Banhart, Real-time Xray Radioscopy on Metallic Foams Using a Compact MicroFocus Source, Adv. Eng. Mater. 6 (6) (2004) 416-420. doi:10.1002/adem.200405143.

[23] A. J. Meagher, M. Mukherjee, D. Weaire, S. Hutzler, J. Banhart, F. Garcia-Moreno, Analysis of the internal structure of monodisperse liquid foams by X-ray tomography, Soft Matter 7 (2011) 9881-9885. doi:10.1039/c1sm05495c.

[24] M. Dierick, B. Masschaele, L. Van Hoorebeke, Octopus, a fast and user-friendly tomographic reconstruction package developed in LabViewß), Meas. Sci. Technol. 15 (7) (2004) 13661370. doi:10.1088/0957-0233/15/7/020.

[25] Volume Graphics GmbH, Heidelberg, VGStudio MAX (2011). URL http://www . volumegraphics.com

[26] M. V. Twigg, J. T. Richardson, Fundamentals and Applications of Structured Ceramic Foam Catalysts, Ind. Eng. Chem. Res. 46 (12) (2007) 4166-4177. doi:10.1021/ie061122o.

[27] G. Incera Garridoa, F. Patcas, S. Langa, B. KraushaarCzarnetzki, Mass transfer and pressure drop in ceramic foams: A description for different pore sizes and porosities, Chem. Eng. Sci. 63 (21) (2008) 5202-5217. doi:10.1016/j.ces.2008.06.015.

[28] I. B. Gornushkin, P. E. Eagan, A. B. Novikov, B. W. Smith, J. D. Winefordner, Automatic Correction of Continuum Background in Laser-Induced Breakdown and Raman Spectrometry, Appl. Spectrosc. 57 (2) (2003) 197-207.

URL www . opticsinfobase. org/abstract. cfm?URI=as-57-2-197

[29] O. Deutschmann, L. D. Schmidt, Modeling the partial oxidation of methane in a short-contact-time reactor, AIChE J. 44 (11) (1998) 2465-2477. doi:10.1002/aic.690441114.

[30] Reaction Design: San Diego, Chemkin-pro 15101 (2011). URL http://www.reactiondesign.com

[31] R. Quiceno, J. Pérez-Ramírez, J. Warnatz, O. Deutschmann, Modeling the high-temperature catalytic partial oxidation of methane over platinum gauze: Detailed gas-phase and surface chemistries coupled with 3D flow field simulations, Appl. Catal. A 303 (2006) 166-176. doi:10.1016/j.apcata.2006.01.041.

[32] J. Koop, O. Deutschmann, Detailed surface reaction mechanism for Pt-catalyzed abatement of automotive exhaust gases, Appl. Catal., B 91 (1-2) (2009) 47-58. doi:10.1016/j.apcatb.2009.05.006.

[33] A. B. Mhadeshwar, D. G. Vlachos, A Catalytic Reaction Mechanism for Methane Partial Oxidation at Short Contact Times, Reforming, and Combustion, and for Oxygenate Decomposition and Oxidation on Platinum., Ind. Eng. Chem. Res. 46 (16) (2007) 5310-5324. doi:10.1021/ie070322c.

[34] W. Hauptmann, M. Votsmeier, H. Vogel, D. G. Vlachos, Modeling the simultaneous oxidation of $\mathrm{CO}$ and $\mathrm{H}_{2}$ on $\mathrm{Pt}-$ Promoting effect of $\mathrm{H}_{2}$ on the CO-light-off, Appl. Catal., A 397 (1-2) (2011) 174-182. doi:10.1016/j.apcata.2011.02.031.

[35] O. Korup, M. Geske, S. Mavlyankariev, R. Schlögl, R. Horn, Catalytic partial oxidation of methane on autothermally operated Pt catalysts: Reaction pathways, zoning effects, and impact of mass and heat transport, Prepr. Pap. - Am. Chem. Soc. Div. Fuel Chem. 55 (2) (2010) 149-150.

[36] R. Horn, O. Korup, M. Geske, U. Zavyalova, I. Oprea, R. Schlögl, Reactor for In-Situ Measurements of Spatially Resolved Kinetic Data in Heterogeneous Catalysis, Rev. Sci. Instrum. 81 (6) (2010) 064102. doi:10.1063/1.3428727.

[37] D. K. Zerkle, M. D. Allendorf, M. Wolf, O. Deutschmann, Understanding Homogeneous and Heterogeneous Contributions to the Platinum-Catalyzed Partial Oxidation of Ethane in a Short-Contact-Time Reactor, J. Catal. 196 (1) (2000) 18-39. doi:10.1006/jcat.2000.3009.

[38] O. Korup, R. Schlögl, R. Horn, Carbon formation in catalytic partial oxidation of methane on platinum: Model studies on a polycrystalline Pt foil, Catal. Today 181 (1) (2012) 177-183. doi:10.1016/j.cattod.2011.04.051.

[39] R. S. Krishnan, Raman spectrum of alumina and the luminescence of ruby, Nature $160 \quad$ (4053) (1947) 26. doi:10.1038/160026a0.

[40] R. S. Krishnan, Raman spectrum of alumina and the luminescence of ruby, Proceedings Mathematical Sciences 26 (6) (1947) 450-459. doi:10.1007/BF03170901.

[41] A. C. Ferrari, J. Robertson, Interpretation of Raman spectra of disordered and amorphous carbon, Phys. Rev. B 61 (20) (2000) 14095-14107. doi:10.1103/PhysRevB.61.14095.

[42] A. Sadezky, H. Muckenhuber, H. Grothe, R. Niessner, U. Pöschl, Raman microspectroscopy of soot and related carbonaceous materials: Spectral analysis and structural information, Carbon 43 (5) (2005) 1731-1742. doi:10.1016/j.carbon.2005.02.018.

[43] F. Tuinstra, J. L. Koenig, Raman Spectrum of Graphite, J. Phys. Chem. 53 (3) (1970) 1126-1130. doi:10.1063/1.1674108.

44] G. Katagiri, H. Ishida, A. Ishitani, Raman spectra of graphite edge planes, Carbon 26 (4) (1988) 565-571. doi:10.1016/00086223(88)90157-1.

[45] Y. Wang, D. C. Alsmeyer, R. L. McCreery, Raman spectroscopy of carbon materials: structural basis of observed spectra, Chem. Mater. 2 (5) (1990) 557-563. doi:10.1021/cm00011a018.

[46] N. P. Ivleva, U. McKeon, R. Niessner, U. Pöschl, Raman Microspectroscopic Analysis of Size-Resolved Atmospheric Aerosol Particle Samples Collected with an ELPI: Soot, Humic-Like Substances, and Inorganic Compounds, Aerosol Sci. Technol. 41 (7) (2007) 655-671. doi:10.1080/02786820701376391.

[47] M. Knauer, M. E. Schuster, D. Su, R. Schlögl, R. Niessner, N. P. Ivleva, Soot Structure and Reactivity Analysis by Raman Microspectroscopy, Temperature-Programmed Oxidation, and High-Resolution Transmission Electron Microscopy, J. Phys. Chem. A 113 (50) (2009) 13871-13880. doi:10.1021/jp905639d.

[48] B. Dippel, H. Jander, J. Heintzenberg, NIR FT Raman spectroscopic study of flame soot, Phys. Chem. Chem. Phys. 1 (1999) 4707-4712. doi:10.1039/A904529E.

[49] B. Dippel, J. Heintzenberg, Soot characterization in atmospheric particles from different sources by NIR FT Raman spectroscopy, J. Aerosol Sci. 30 (1999) S907-S908. doi:10.1016/S0021-8502(99)80464-9.

50] A. Cuesta, P. Dhamelincourt, J. Laureyns, A. Martínez-Alonso, J. M. D. Tascón, Raman microprobe studies on carbon materials, Carbon 32 (8) (1994) 1523-1532. doi:10.1016/00086223(94)90148-1.

[51] E. J. Nowak, Catalytic oxidation of ammonia on platinum, Chem. Eng. Sci. 21 (1) (1966) 19-27. doi:10.1016/00092509(66)80003-9.

[52] R. W. McCabe, T. Pignet, L. D. Schmidt, Catalytic etching of platinum in $\mathrm{NH}_{3}$ oxidation, J. Catal. 32 (1) (1974) 114-126. doi:10.1016/0021-9517(74)90165-1.

[53] R. W. McCabe, G. D. W. Smith, A. S. Pratt, The Mechanism of Reconstruction of Rhodium-Platinum Catalyst Gauzes, Platinum Metals Rev. 30 (2) (1986) 54-62. URL http://www.platinummetalsreview . com/pdf/pmr-v30-i2-054-062

[54] V. W. Dean, M. Frenklach, J. Phillips, Catalytic etching of platinum foils and thin films in hydrogen-oxygen mixtures, J. Phys. Chem. 92 (20) (1988) 5731-5738. doi:10.1021/j100331a037.

[55] C. F. Goldsmith, Top. Catal. (in press) (2012) (in press).

\section{Appendix: Reaction Mechanisms}


Table 4: Deutschmann surface reaction mechanism of C1 oxidation on Pt adopted from [31, 32, 37], changed.

\begin{tabular}{|c|c|c|c|c|}
\hline $\begin{array}{l}\text { reaction } \\
\text { step }\end{array}$ & reaction & $\begin{array}{l}\text { pre-exponential } \\
\text { factor }^{\mathrm{a}}\end{array}$ & $\begin{array}{l}\text { temperature } \\
\text { exponent, } \beta\end{array}$ & $\begin{array}{l}\text { activation energy } \\
\left(\mathrm{cal} \mathrm{mol}^{-1}\right)\end{array}$ \\
\hline R'1 & \multicolumn{4}{|c|}{ Adsorption-desorption reactions } \\
\hline $\mathrm{R}^{\prime} 2$ & $\mathrm{CH}_{3}(\mathrm{~s})+\mathrm{H}(\mathrm{s}) \rightarrow \mathrm{CH}_{4}+2 \mathrm{Pt}(\mathrm{s})$ & $3.300 \times 10^{21}$ & 0.0 & $11942-669 \theta_{\mathrm{H}(\mathrm{s})}$ \\
\hline $\mathrm{R}^{\prime} 3^{\mathrm{d}}$ & $\mathrm{O}_{2}+2 \mathrm{Pt}(\mathrm{s}) \rightarrow 2 \mathrm{O}(\mathrm{s})$ & 0.070 & 0.0 & 0.0 \\
\hline R'4 & $2 \mathrm{O}(\mathrm{s}) \rightarrow \mathrm{O}_{2}+2 \mathrm{Pt}(\mathrm{s})$ & $3.218 \times 10^{21}$ & 0.0 & $53671-28662 \theta_{\mathrm{O}(\mathrm{s})}$ \\
\hline R'5 & $\mathrm{H}_{2}+2 \mathrm{Pt}(\mathrm{s}) \rightarrow 2 \mathrm{H}(\mathrm{s})$ & 0.046 & 0.0 & 0.0 \\
\hline $\mathrm{R}^{\prime} 6$ & $2 \mathrm{H}(\mathrm{s}) \rightarrow \mathrm{H}_{2}+2 \mathrm{Pt}(\mathrm{s})$ & $2.121 \times 10^{21}$ & 0.0 & $16507-1433 \theta_{\mathrm{H}(\mathrm{s})}$ \\
\hline $\mathrm{R}^{\prime} 7$ & $\mathrm{H}_{2} \mathrm{O}+\mathrm{Pt}(\mathrm{s}) \rightarrow \mathrm{H}_{2} \mathrm{O}(\mathrm{s})$ & $7.500 \times 10^{-1}$ & 0.0 & 0.0 \\
\hline R'8 & $\mathrm{H}_{2} \mathrm{O}(\mathrm{s}) \rightarrow \mathrm{H}_{2} \mathrm{O}+\mathrm{Pt}(\mathrm{s})$ & $5.013 \times 10^{12}$ & 0.0 & 11742 \\
\hline R'9 & $\mathrm{CO}+\mathrm{Pt}(\mathrm{s}) \rightarrow \mathrm{CO}(\mathrm{s})$ & $8.400 \times 10^{-1}$ & 0.0 & 0.0 \\
\hline R'10 & $\mathrm{CO}(\mathrm{s}) \rightarrow \mathrm{CO}+\mathrm{Pt}(\mathrm{s})$ & $2.126 \times 10^{13}$ & 0.0 & $32528-7882 \theta_{\mathrm{CO}}(\mathrm{s})$ \\
\hline R'11 & $\mathrm{CO}_{2}+\mathrm{Pt}(\mathrm{s}) \rightarrow \mathrm{CO}_{2}(\mathrm{~s})$ & $5.000 \times 10^{-3}$ & 0.0 & 0.0 \\
\hline $\mathrm{R}^{\prime} 12$ & $\mathrm{CO}_{2}(\mathrm{~s}) \rightarrow \mathrm{CO}_{2}+\mathrm{Pt}(\mathrm{s})$ & $3.565 \times 10^{10}$ & 0.0 & 5651 \\
\hline $\mathrm{R}^{\prime} 13$ & $\mathrm{CH}_{4}+\mathrm{O}(\mathrm{s})+\mathrm{Pt}(\mathrm{s}) \rightarrow \mathrm{CH}_{3}(\mathrm{~s})+\mathrm{OH}(\mathrm{s})$ & $5.000 \times 10^{18}$ & 0.7 & $10032+1911 \theta_{\mathrm{O}(\mathrm{s})}$ \\
\hline $\begin{array}{l}\mathrm{R}^{\prime} 14 \\
\mathrm{R} \cdot 15\end{array}$ & $\begin{array}{l}\mathrm{CH}_{3}(\mathrm{~s})+\mathrm{OH}(\mathrm{s}) \rightarrow \mathrm{CH}_{4}+\mathrm{O}(\mathrm{s})+\mathrm{Pt}(\mathrm{s}) \\
\mathrm{CH}_{4}+\mathrm{OH}(\mathrm{s})+\mathrm{Pt}(\mathrm{s}) \rightarrow \mathrm{CH}_{3}(\mathrm{~s})+\mathrm{H}_{2} \mathrm{O}(\mathrm{s})\end{array}$ & $\begin{array}{l}3.700 \times 10^{21} \\
1.000\end{array}$ & $\begin{array}{l}0.0 \\
0.0\end{array}$ & $\begin{array}{l}20995 \\
2388\end{array}$ \\
\hline \multicolumn{5}{|c|}{$\mathrm{CH}_{3}(\mathrm{~s})+\mathrm{H}_{2} \mathrm{O}(\mathrm{s}) \rightarrow \mathrm{CH}_{4}+\mathrm{OH}(\mathrm{s})+\mathrm{Pt}(\mathrm{s})$} \\
\hline R'17 & $\mathrm{CH}_{3}(\mathrm{~s})+\mathrm{Pt}(\mathrm{s}) \rightarrow \mathrm{CH}_{2}(\mathrm{~s})+\mathrm{H}(\mathrm{s})$ & $1.262 \times 10^{22}$ & 0.0 & 16815 \\
\hline R'18 & $\mathrm{CH}_{2}(\mathrm{~s})+\mathrm{H}(\mathrm{s}) \rightarrow \mathrm{CH}_{3}(\mathrm{~s})+\mathrm{Pt}(\mathrm{s})$ & $2.943 \times 10^{22}$ & 0.0 & $98-669 \theta_{\mathrm{H}(\mathrm{s})} \mathrm{b}$ \\
\hline R'19 & $\mathrm{CH}_{2}(\mathrm{~s})+\mathrm{Pt}(\mathrm{s}) \rightarrow \mathrm{CH}(\mathrm{s})+\mathrm{H}(\mathrm{s})$ & $7.000 \times 10^{22}$ & 0.0 & $14140+11942 \theta_{\mathrm{C}(\mathrm{s})} \mathrm{b}$ \\
\hline $\mathrm{R}^{\prime} 20$ & $\mathrm{CH}(\mathrm{s})+\mathrm{H}(\mathrm{s}) \rightarrow \mathrm{CH}_{2}(\mathrm{~s})+\mathrm{Pt}(\mathrm{s})$ & $8.110 \times 10^{21}$ & 0.0 & $170-669 \theta_{\mathrm{H}(\mathrm{s})} \mathrm{b}^{\mathrm{s})}$ \\
\hline$\left(\mathrm{R}^{\prime} 21 \equiv \mathrm{R} 27\right)^{\mathrm{c}}$ & $\mathrm{CH}(\mathrm{s})+\mathrm{Pt}(\mathrm{s}) \rightarrow \mathrm{C}(\mathrm{s})+\mathrm{H}(\mathrm{s})$ & $3.460 \times 10^{18}$ & 0.398 & 31300 \\
\hline$\left(\mathrm{R}^{\prime} 22 \equiv \mathrm{R} 28\right)^{\mathrm{C}}$ & $\mathrm{C}(\mathrm{s})+\mathrm{H}(\mathrm{s}) \rightarrow \mathrm{CH}(\mathrm{s})+\mathrm{Pt}(\mathrm{s})$ & $3.910 \times 10^{20}$ & -0.398 & 13200 \\
\hline $\mathrm{R}^{\prime} 23$ & $\mathrm{CH}_{3}(\mathrm{~s})+\mathrm{O}(\mathrm{s}) \rightarrow \mathrm{OH}(\mathrm{s})+\mathrm{CH}_{2}(\mathrm{~s})$ & $3.700^{21}$ & 0.0 & 8741 \\
\hline $\mathrm{R}^{\prime} 24$ & $\mathrm{OH}(\mathrm{s})+\mathrm{CH}_{2}(\mathrm{~s}) \rightarrow \mathrm{CH}_{3}(\mathrm{~s})+\mathrm{O}(\mathrm{s})$ & $2.342 \times 10^{22}$ & 0.0 & 6205 \\
\hline$R^{\prime} 25$ & $\mathrm{CH}_{2}(\mathrm{~s})+\mathrm{O}(\mathrm{s}) \rightarrow \mathrm{OH}(\mathrm{s})+\mathrm{CH}(\mathrm{s})$ & $3.700 \times 10^{21}$ & 0.0 & 5995 \\
\hline R'26 & $\mathrm{OH}(\mathrm{s})+\mathrm{CH}(\mathrm{s}) \rightarrow \mathrm{CH}_{2}(\mathrm{~s})+\mathrm{O}(\mathrm{s})$ & $1.163 \times 10^{21}$ & 0.0 & 6401 \\
\hline $\mathrm{R}^{\prime} 27$ & $\mathrm{CH}(\mathrm{s})+\mathrm{O}(\mathrm{s}) \rightarrow \mathrm{OH}(\mathrm{s})+\mathrm{C}(\mathrm{s})$ & $3.700 \times 10^{21}$ & 0.0 & 5995 \\
\hline $\mathrm{R}^{\prime} 28$ & $\mathrm{OH}(\mathrm{s})+\mathrm{C}(\mathrm{s}) \rightarrow \mathrm{CH}(\mathrm{s})+\mathrm{O}(\mathrm{s})$ & $1.882 \times 10^{21}$ & 0.0 & 51151 \\
\hline R'29 & $\mathrm{CO}(\mathrm{s})+\mathrm{O}(\mathrm{s}) \rightarrow \mathrm{CO}_{2}(\mathrm{~s})+\mathrm{Pt}(\mathrm{s}){ }^{\mathrm{CO} \text { oxidat }}$ & $\begin{array}{l}\text { on } \mathrm{Pt} \\
3.700 \times 10^{20}\end{array}$ & 0.0 & $25795-7882 \theta_{\mathrm{CO}(\mathrm{s})}$ \\
\hline $\mathrm{R}^{\prime} 30$ & $\mathrm{CO}_{2}(\mathrm{~s})+\mathrm{Pt}(\mathrm{s}) \rightarrow \mathrm{CO}(\mathrm{s})+\mathrm{O}(\mathrm{s})$ & $3.94 \times 10^{21}$ & 0.0 & $39551+14331 \theta_{\mathrm{O}(\mathrm{s})}$ \\
\hline $\mathrm{R}^{\prime} 31$ & $\mathrm{C}(\mathrm{s})+\mathrm{O}(\mathrm{s}) \rightarrow \mathrm{CO}(\mathrm{s})+\mathrm{Pt}(\mathrm{s})$ & $3.700 \times 10^{21}$ & 0.0 & $0.0-7882 \theta \mathrm{CO}(\mathrm{s})$ \\
\hline $\mathrm{R}^{\prime} 32$ & $\mathrm{CO}(\mathrm{s})+\mathrm{Pt}(\mathrm{s}) \rightarrow \mathrm{C}(\mathrm{s})+\mathrm{O}(\mathrm{s})$ & $1.664 \times 10^{21}$ & 0.0 & $49064+14331 \theta_{\mathrm{O}(\mathrm{s})}$ \\
\hline \multicolumn{5}{|c|}{ Hydroxyl reactions on $\mathrm{Pt}$} \\
\hline $\mathrm{R}^{\prime} 33$ & $\mathrm{H}(\mathrm{s})+\mathrm{O}(\mathrm{s}) \rightarrow \mathrm{OH}(\mathrm{s})+\mathrm{Pt}(\mathrm{s})$ & $3.700 \times 10^{20}$ & 0.0 & 16839 \\
\hline $\mathrm{R}^{\prime} 34$ & $\mathrm{OH}(\mathrm{s})+\mathrm{Pt}(\mathrm{s}) \rightarrow \mathrm{H}(\mathrm{s})+\mathrm{O}(\mathrm{s})$ & $1.004 \times 10^{21}$ & 0.0 & $31215-17488 \theta_{\mathrm{O}(\mathrm{s})}^{\mathrm{b}}$ \\
\hline R'35 & $\mathrm{H}(\mathrm{s})+\mathrm{OH}(\mathrm{s}) \rightarrow \mathrm{H}_{2} \mathrm{O}(\mathrm{s})+\mathrm{Pt}(\mathrm{s})$ & $3.700 \times 10^{21}$ & 0.0 & 4156 \\
\hline R'36 & $\mathrm{H}_{2} \mathrm{O}(\mathrm{s})+\mathrm{Pt}(\mathrm{s}) \rightarrow \mathrm{H}(\mathrm{s})+\mathrm{OH}(\mathrm{s})$ & $6.824 \times 10^{20}$ & 0.0 & $16136+39973 \theta_{\mathrm{O}(\mathrm{s})}^{\mathrm{b}}$ \\
\hline $\mathrm{R}^{\prime} 37$ & $2 \mathrm{OH}(\mathrm{s}) \rightarrow \mathrm{H}_{2} \mathrm{O}(\mathrm{s})+\mathrm{O}(\mathrm{s})$ & $3.700 \times 10^{21}$ & 0.0 & 11512 \\
\hline $\mathrm{R}^{\prime} 38$ & $\mathrm{H}_{2} \mathrm{O}(\mathrm{s})+\mathrm{O}(\mathrm{s}) \rightarrow 2 \mathrm{OH}(\mathrm{s})$ & $2.515 \times 10^{20}$ & 0.0 & $9117+57462 \theta_{\mathrm{O}(\mathrm{s})}^{\mathrm{b}}$ \\
\hline R'39 & $\mathrm{CO}(\mathrm{s})+\mathrm{OH}(\mathrm{s}) \rightarrow \mathrm{HCOO}(\mathrm{s})+\mathrm{Pt}(\mathrm{s})$ & $3.700 \times 10^{21}$ & 0.0 & 22499 \\
\hline R'40 & $\mathrm{HCOO}(\mathrm{s})+\mathrm{Pt}(\mathrm{s}) \rightarrow \mathrm{CO}(\mathrm{s})+\mathrm{OH}(\mathrm{s})$ & $1.333 \times 10^{21}$ & 0.0 & 208 \\
\hline R'41 & $\mathrm{HCOO}(\mathrm{s})+\mathrm{O}(\mathrm{s}) \rightarrow \mathrm{OH}(\mathrm{s})+\mathrm{CO}_{2}(\mathrm{~s})$ & $3.700 \times 10^{21}$ & 0.0 & 0.0 \\
\hline R'42 & $\mathrm{OH}(\mathrm{s})+\mathrm{CO}_{2}(\mathrm{~s}) \rightarrow \mathrm{HCOO}(\mathrm{s})+\mathrm{O}(\mathrm{s})$ & $2.787 \times 10^{21}$ & 0.0 & 36078 \\
\hline R'43 & $\mathrm{HCOO}(\mathrm{s})+\mathrm{Pt}(\mathrm{s}) \rightarrow \mathrm{H}(\mathrm{s})+\mathrm{CO}_{2}(\mathrm{~s})$ & $3.700 \times 10^{21}$ & 0.0 & 0.0 \\
\hline R'44 & $\mathrm{H}(\mathrm{s})+\mathrm{CO}_{2}(\mathrm{~s}) \rightarrow \mathrm{HCOO}(\mathrm{s})+\mathrm{Pt}(\mathrm{s})$ & $2.787 \times 10^{21}$ & 0.0 & 21508 \\
\hline R'45 & $\mathrm{CO}(\mathrm{s})+\mathrm{OH}(\mathrm{s}) \rightarrow \mathrm{CO}_{2}(\mathrm{~s})+\mathrm{H}(\mathrm{s})$ & $1.000 \times 10^{19}$ & 0.0 & $9243-7165 \theta_{\mathrm{CO}}(\mathrm{s})$ \\
\hline R'46 & $\mathrm{CO}_{2}(\mathrm{~s})+\mathrm{H}(\mathrm{s}) \rightarrow \mathrm{CO}(\mathrm{s})+\mathrm{OH}(\mathrm{s})$ & $1.000 \times 10^{19}$ & 0.0 & 2006 \\
\hline
\end{tabular}

\footnotetext{
${ }^{a}$ Sticking coefficient [dimensionless]; pre-exponential factor for unimolecular reaction $\left[\mathrm{s}^{-1}\right]$; pre-exponential factor for bimolecular reaction $\left[\mathrm{cm}^{2} \mathrm{~mol}^{-1} \mathrm{~s}^{-1}\right]$

${ }^{b}$ The coverage dependency of this species is not used. Preliminary calcuations demonstrated that the surface coverage was too low to matter, and that including it led to significant numerical instabilities.

${ }^{c}$ Here the parameters from the Vlachos mechanism are used, because the original Deutschmann reaction rate from [32] is suspiciously high and led to numerical instabilities.

${ }^{d}$ The desorption rate constant as written leads to numerical instability. To obtain a converging solution, the rate constant for desorption was obtained directly from the equilibrium constant, as detailed in [55].
} 
Table 5: Vlachos surface reaction mechanism of $\mathrm{C} 1$ oxidation on $\mathrm{Pt}$ adopted from [33, 34], changed.

\begin{tabular}{|c|c|c|c|c|}
\hline $\begin{array}{l}\text { reaction } \\
\text { step }\end{array}$ & reaction & $\begin{array}{l}\text { pre-exponential } \\
\text { factor }^{\mathrm{a}}\end{array}$ & $\begin{array}{l}\text { temperature } \\
\text { exponent, } \beta\end{array}$ & $\begin{array}{l}\text { activation energy } \\
\left(\text { cal } \mathrm{mol}^{-1}\right)\end{array}$ \\
\hline \multicolumn{5}{|c|}{ Oxygen adsorption-desorption steps } \\
\hline R1 & $\mathrm{O}_{2}+2 \mathrm{Pt}(\mathrm{s}) \rightarrow 2 \mathrm{O}(\mathrm{s})$ & $6.86 \times 10^{-4}$ & 0.766 & 0.0 \\
\hline R2 & $2 \mathrm{O}(\mathrm{s}) \rightarrow \mathrm{O}_{2}+\mathrm{Pt}(\mathrm{s})$ & $1.54 \times 10^{19}$ & 0.930 & $50396.5-32005.4 \theta_{\mathrm{O}(\mathrm{s})}$ \\
\hline \multicolumn{5}{|c|}{$\mathrm{CO}$ oxydation on $\mathrm{Pt}$} \\
\hline R3 & $\mathrm{CO}+\mathrm{Pt}(\mathrm{s}) \rightarrow \mathrm{CO}(\mathrm{s})$ & $1.00 \times 10^{0}$ & 0.000 & 0.0 \\
\hline R4 & $\mathrm{CO}(\mathrm{s}) \rightarrow \mathrm{CO}+\mathrm{Pt}(\mathrm{s})$ & $6.12 \times 10^{14}$ & 0.390 & $41320.4-15047.3 \theta_{\mathrm{CO}(\mathrm{s})}$ \\
\hline R5 & $\mathrm{CO}_{2}+\mathrm{Pt}(\mathrm{s}) \rightarrow \mathrm{CO}_{2}(\mathrm{~s})$ & $4.69 \times 10^{-2}$ & 0.250 & 0.0 \\
\hline R6 & $\mathrm{CO}_{2}(\mathrm{~s}) \rightarrow \mathrm{CO}_{2}+\mathrm{Pt}(\mathrm{s})$ & $1.51 \times 10^{13}$ & -0.250 & 2866.2 \\
\hline R7 & $\mathrm{CO}_{2}(\mathrm{~s})+\mathrm{Pt}(\mathrm{s}) \rightarrow \mathrm{CO}(\mathrm{s})+\mathrm{O}(\mathrm{s})$ & $5.14 \times 10^{19}$ & -0.280 & $29855.8+7643.1 \theta_{\mathrm{O}(\mathrm{s})}+11464.6 \theta_{\mathrm{CO}(\mathrm{s})}$ \\
\hline $\mathrm{R} 8$ & $\mathrm{CO}(\mathrm{s})+\mathrm{O}(\mathrm{s}) \rightarrow \mathrm{CO}_{2}(\mathrm{~s})+\mathrm{Pt}(\mathrm{s})$ & $4.32 \times 10^{18}$ & 0.460 & $25795.4-8359.6 \theta_{\mathrm{O}(\mathrm{s})}-3582.7 \theta_{\mathrm{CO}(\mathrm{s})}$ \\
\hline \multicolumn{5}{|c|}{$\mathrm{H}_{2}$ oxidation on $\mathrm{Pt}$} \\
\hline R9 & $\mathrm{H}_{2}+2 \mathrm{Pt}(\mathrm{s}) \rightarrow 2 \mathrm{H}(\mathrm{s})$ & $9.67 \times 10^{-4}$ & 0.858 & 0.0 \\
\hline R10 & $2 \mathrm{H}(\mathrm{s}) \rightarrow \mathrm{H}_{2}+2 \mathrm{Pt}(\mathrm{s})$ & $5.43 \times 10^{16}$ & 1.910 & $19346.5-5971.2 \theta_{H(s)}$ \\
\hline R11 & $\mathrm{OH}(\mathrm{s})+\mathrm{Pt}(\mathrm{s}) \rightarrow \mathrm{H}(\mathrm{s})+\mathrm{O}(\mathrm{s})$ & $3.64 \times 10^{17}$ & 1.330 & $\begin{array}{l}26989.6-10031.5 \theta_{\mathrm{O}(\mathrm{s})}+955.4 \theta_{\mathrm{H}(\mathrm{s})} \\
+12420.0 \theta_{\mathrm{H}_{2} \mathrm{O}(\mathrm{s})} \mathrm{b}\end{array}$ \\
\hline R12 & $\mathrm{H}(\mathrm{s})+\mathrm{O}(\mathrm{s}) \rightarrow \mathrm{OH}(\mathrm{s})+\mathrm{Pt}(\mathrm{s})$ & $4.92 \times 10^{18}$ & 1.080 & $\begin{array}{l}8598.5+6926.5 \theta_{\mathrm{O}(\mathrm{s})}-1910.8 \theta_{\mathrm{H}(\mathrm{s})} \\
-12420.0 \theta_{\mathrm{H}_{2} \mathrm{O}(\mathrm{s})} \mathrm{b}\end{array}$ \\
\hline R13 & $\mathrm{H}_{2} \mathrm{O}(\mathrm{s})+\mathrm{Pt}(\mathrm{s}) \rightarrow \mathrm{H}(\mathrm{s})+\mathrm{OH}(\mathrm{s})$ & $3.18 \times 10^{22}$ & -0.390 & $\begin{array}{l}17674.6+11225.8 \theta_{\mathrm{O}(\mathrm{s})}^{\mathrm{b}}+1194.2 \theta_{\mathrm{H}(\mathrm{s})} \\
+12420.0 \theta_{\mathrm{OH}(\mathrm{s})}-10986.0 \theta_{\mathrm{H}_{2} \mathrm{O}}\end{array}$ \\
\hline R14 & $\mathrm{H}(\mathrm{s})+\mathrm{OH}(\mathrm{s}) \rightarrow \mathrm{H}_{2} \mathrm{O}(\mathrm{s})+\mathrm{Pt}(\mathrm{s})$ & $3.03 \times 10^{22}$ & -0.370 & $\begin{array}{l}13375.4-21735.0 \theta_{\mathrm{O}(\mathrm{s})} \mathrm{b}-1910.8 \theta_{\mathrm{H}(\mathrm{s})} \\
-12420.0 \theta_{\mathrm{OH}(\mathrm{s})}+16480.4 \theta_{\mathrm{H}_{2} \mathrm{O}}\end{array}$ \\
\hline R15 & $\mathrm{H}_{2} \mathrm{O}(\mathrm{s})+\mathrm{O}(\mathrm{s}) \rightarrow 2 \mathrm{OH}(\mathrm{s})$ & $2.42 \times 10^{18}$ & 0.330 & $8598.5+16719.2 \theta_{\mathrm{O}(\mathrm{s})}+12420.0 \theta_{\mathrm{OH}(\mathrm{s})}$ \\
\hline R16 & $2 \mathrm{OH}(\mathrm{s}) \rightarrow \mathrm{H}_{2} \mathrm{O}(\mathrm{s})+\mathrm{O}(\mathrm{s})$ & $3.04 \times 10^{17}$ & 0.530 & $\begin{array}{l}22690.4-33199.6 \theta \mathrm{O}(\mathrm{s})-12420.0 \theta \mathrm{OH}(\mathrm{s}) \\
+32483.1 \theta \mathrm{H}_{2} \mathrm{O}(\mathrm{s})\end{array}$ \\
\hline R17 & $\mathrm{H}_{2} \mathrm{O}+\mathrm{Pt}(\mathrm{s}) \rightarrow \mathrm{H}_{2} \mathrm{O}(\mathrm{s})$ & $1.45 \times 10^{-4}$ & 1.160 & 0.0 \\
\hline R18 & $\mathrm{H}_{2} \mathrm{O}(\mathrm{s}) \rightarrow \mathrm{H}_{2} \mathrm{O}+\mathrm{Pt}(\mathrm{s})$ & $1.38 \times 10^{6}$ & 2.490 & $9553.8+25078.8 \theta_{\mathrm{OH}(\mathrm{s})} \mathrm{b}-2388.5 \theta_{\mathrm{H}_{2} \mathrm{O}(\mathrm{s})}$ \\
\hline R19 & $\mathrm{CO}_{2}(\mathrm{~s})+\mathrm{H}(\mathrm{s}) \rightarrow \mathrm{CO}(\mathrm{s})+\mathrm{OH}(\mathrm{s})$ & $\begin{array}{l}\text { ween } \mathrm{CO} \text { and } \mathrm{H}_{2} \\
1.94 \times 10^{18}\end{array}$ & $\begin{array}{l}\text { lemistry on } \mathrm{Pt} \\
-0.330\end{array}$ & $\begin{array}{l}9553.8+12897.7 \theta_{\mathrm{O}(\mathrm{s})}^{\mathrm{b}}-1433.1 \theta_{\mathrm{H}(\mathrm{s})} \\
-10748.1 \theta_{\mathrm{H}_{2} \mathrm{O}(\mathrm{s})} \mathrm{b}+4299.2 \theta_{\mathrm{CO}(\mathrm{s})}\end{array}$ \\
\hline $\mathrm{R} 20^{\mathrm{d}}$ & $\mathrm{CO}(\mathrm{s})+\mathrm{OH}(\mathrm{s}) \rightarrow \mathrm{CO}_{2}(\mathrm{~s})+\mathrm{H}(\mathrm{s})$ & $4.28 \times 10^{15}$ & 0.820 & $\begin{array}{l}23884.6-20063.1 \theta_{\mathrm{O}(\mathrm{s})} \mathrm{b}+1433.1 \theta_{\mathrm{H}(\mathrm{s})} \\
+14091.9 \theta_{\mathrm{H}_{2} \mathrm{O}(\mathrm{s})}^{\mathrm{b}}-10509.2 \theta_{\mathrm{CO}}(\mathrm{s})\end{array}$ \\
\hline \multicolumn{5}{|c|}{$\mathrm{CH}_{4}$ oxidation and reforming on $\mathrm{Pt}$} \\
\hline R21 & $\mathrm{CH}_{4}+2 \mathrm{Pt}(\mathrm{s}) \rightarrow \mathrm{CH}_{3}(\mathrm{~s})+\mathrm{H}(\mathrm{s})$ & $4.82 \times 10^{-2}$ & 0.154 & 9000 \\
\hline R22 & $\mathrm{CH}_{3}(\mathrm{~s})+\mathrm{H}(\mathrm{s}) \rightarrow \mathrm{CH}_{4}+2 \mathrm{Pt}(\mathrm{s})$ & $5.42 \times 10^{19}$ & -0154 & 11300 \\
\hline R23 & $\mathrm{CH}_{3}(\mathrm{~s})+\mathrm{Pt}(\mathrm{s}) \rightarrow \mathrm{CH}_{2}(\mathrm{~s})+\mathrm{H}(\mathrm{s})$ & $3.74 \times 10^{17}$ & 0.419 & 15800 \\
\hline R24 & $\mathrm{CH}_{2}(\mathrm{~s})+\mathrm{H}(\mathrm{s}) \rightarrow \mathrm{CH}_{3}(\mathrm{~s})+\mathrm{Pt}(\mathrm{s})$ & $3.61 \times 10^{19}$ & -0419 & 13300 \\
\hline R25 & $\mathrm{CH}_{2}(\mathrm{~s})+\mathrm{Pt}(\mathrm{s}) \rightarrow \mathrm{CH}(\mathrm{s})+\mathrm{H}(\mathrm{s})$ & $5.41 \times 10^{18}$ & 0.222 & 9000 \\
\hline R26 & $\mathrm{CH}(\mathrm{s})+\mathrm{H}(\mathrm{s}) \rightarrow \mathrm{CH}_{2}(\mathrm{~s})+\mathrm{Pt}(\mathrm{s})$ & $2.50 \times 10^{20}$ & -0.222 & 35400 \\
\hline $\mathrm{R} 27$ & $\mathrm{CH}(\mathrm{s})+\mathrm{Pt}(\mathrm{s}) \rightarrow \mathrm{C}(\mathrm{s})+\mathrm{H}(\mathrm{s})$ & $3.46 \times 10^{18}$ & 0.398 & 31300 \\
\hline R28 & $\mathrm{C}(\mathrm{s})+\mathrm{H}(\mathrm{s}) \rightarrow \mathrm{CH}(\mathrm{s})+\mathrm{Pt}(\mathrm{s})$ & $3.91 \times 10^{20}$ & -0.398 & 13200 \\
\hline R29 & $\mathrm{CH}_{3}(\mathrm{~s})+\mathrm{O}(\mathrm{s}) \rightarrow \mathrm{CH}_{2}(\mathrm{~s})+\mathrm{OH}(\mathrm{s})$ & $2.69 \times 10^{20}$ & -0.230 & 10800 \\
\hline R30 & $\mathrm{CH}_{2}(\mathrm{~s})+\mathrm{OH}(\mathrm{s}) \rightarrow \mathrm{CH}_{3}(\mathrm{~s})+\mathrm{O}(\mathrm{s})$ & $5.03 \times 10^{18}$ & 0.230 & 26600 \\
\hline R31 & $\mathrm{CH}_{2}(\mathrm{~s})+\mathrm{O}(\mathrm{s}) \rightarrow \mathrm{CH}(\mathrm{s})+\mathrm{OH}(\mathrm{s})$ & $3.55 \times 10^{20}$ & -0.414 & 0.0 \\
\hline R32 & $\mathrm{CH}(\mathrm{s})+\mathrm{OH}(\mathrm{s}) \rightarrow \mathrm{CH}_{2}(\mathrm{~s})+\mathrm{O}(\mathrm{s})$ & $3.81 \times 10^{18}$ & 0.414 & 44700 \\
\hline R33 & $\mathrm{CH}(\mathrm{s})+\mathrm{O}(\mathrm{s}) \rightarrow \mathrm{C}(\mathrm{s})+\mathrm{OH}(\mathrm{s})$ & $2.08 \times 10^{20}$ & -0.225 & 27500 \\
\hline R34 & $\mathrm{C}(\mathrm{s})+\mathrm{OH}(\mathrm{s}) \rightarrow \mathrm{CH}(\mathrm{s})+\mathrm{O}(\mathrm{s})$ & $6.49 \times 10^{18}$ & 0.225 & 27700 \\
\hline R35 & $\mathrm{CH}_{2}(\mathrm{~s})+\mathrm{H}_{2} \mathrm{O}(\mathrm{s}) \rightarrow \mathrm{CH}_{3}(\mathrm{~s})+\mathrm{OH}(\mathrm{s})$ & $1.71 \times 10^{19}$ & 0.099 & 14100 \\
\hline R36 & $\mathrm{CH}_{3}(\mathrm{~s})+\mathrm{OH}(\mathrm{s}) \rightarrow \mathrm{CH}_{2}(\mathrm{~s})+\mathrm{H}_{2} \mathrm{O}(\mathrm{s})$ & $7.89 \times 10^{19}$ & -0.099 & 12300 \\
\hline R37 & $\mathrm{CH}(\mathrm{s})+\mathrm{H}_{2} \mathrm{O}(\mathrm{s}) \rightarrow \mathrm{CH}_{2}(\mathrm{~s})+\mathrm{OH}(\mathrm{s})$ & $1.43 \times 10^{19}$ & 0.269 & 34000 \\
\hline R38 & $\mathrm{CH}_{2}(\mathrm{~s})+\mathrm{OH}(\mathrm{s}) \rightarrow \mathrm{CH}(\mathrm{s})+\mathrm{H}_{2} \mathrm{O}(\mathrm{s})$ & $9.43 \times 10^{19}$ & -0.269 & 3300 \\
\hline R39 & $\mathrm{C}(\mathrm{s})+\mathrm{H}_{2} \mathrm{O}(\mathrm{s}) \rightarrow \mathrm{CH}(\mathrm{s})+\mathrm{OH}(\mathrm{s})$ & $2.29 \times 10^{19}$ & 0.090 & 15600 \\
\hline R40 & $\mathrm{CH}(\mathrm{s})+\mathrm{OH}(\mathrm{s}) \rightarrow \mathrm{C}(\mathrm{s})+\mathrm{H}_{2} \mathrm{O}(\mathrm{s})$ & $5.90 \times 10^{19}$ & -0.090 & 29300 \\
\hline R41 & $\mathrm{CO}(\mathrm{s})+\mathrm{Pt}(\mathrm{s}) \rightarrow \mathrm{C}(\mathrm{s})+\mathrm{O}(\mathrm{s})$ & $7.26 \times 10^{18}$ & 0.468 & 76800 \\
\hline R42 & $\mathrm{C}(\mathrm{s})+\mathrm{O}(\mathrm{s}) \rightarrow \mathrm{CO}(\mathrm{s})+\mathrm{Pt}(\mathrm{s})$ & $1.86 \times 10^{20}$ & -0.468 & 22300 \\
\hline R43 & $\mathrm{CO}(\mathrm{s})+\mathrm{H}(\mathrm{s}) \rightarrow \mathrm{CH}(\mathrm{s})+\mathrm{O}(\mathrm{s})$ & $7.56 \times 10^{18}$ & 0.073 & 45800 \\
\hline R44 & $\mathrm{CH}(\mathrm{s})+\mathrm{O}(\mathrm{s}) \rightarrow \mathrm{CO}(\mathrm{s})+\mathrm{H}(\mathrm{s})$ & $1.79 \times 10^{18}$ & -0.073 & 9300 \\
\hline R45 & $\mathrm{CO}(\mathrm{s})+\mathrm{H}(\mathrm{s}) \rightarrow \mathrm{C}(\mathrm{s})+\mathrm{OH}(\mathrm{s})$ & $1.91 \times 10^{20}$ & -0.168 & 40700 \\
\hline R46 & $\mathrm{C}(\mathrm{s})+\mathrm{OH}(\mathrm{s}) \rightarrow \mathrm{CO}(\mathrm{s})+\mathrm{H}(\mathrm{s})$ & $1.14 \times 10^{18}$ & 0.168 & 4400 \\
\hline R47 & $2 \mathrm{CO}(\mathrm{s}) \rightarrow \mathrm{C}(\mathrm{s})+\mathrm{CO}_{2}(\mathrm{~s})$ & $2.32 \times 10^{20}$ & 0.393 & 48800 \\
\hline R48 & $\mathrm{C}(\mathrm{s})+\mathrm{CO}_{2}(\mathrm{~s}) \rightarrow 2 \mathrm{CO}(\mathrm{s})$ & eactions of $\mathrm{COOH}$ on $\mathrm{Pt}$ & $\begin{array}{l}-0.393 \\
\mathrm{Pt}\end{array}$ & 0.0 \\
\hline R49 & $\mathrm{COOH}(\mathrm{s})+\mathrm{Pt}(\mathrm{s}) \rightarrow \mathrm{CO}(\mathrm{s})+\mathrm{OH}(\mathrm{s})$ & $2.61 \times 10^{17}$ & 0.030 & $\begin{array}{l}8837.3+12897.7 \theta_{\mathrm{O}(\mathrm{s})}^{\mathrm{b}}-10748.1 \theta_{\mathrm{H}_{2} \mathrm{O}(\mathrm{s})}^{\mathrm{b}} \\
+4299.2 \theta_{\mathrm{CO}(\mathrm{s})}\end{array}$ \\
\hline $\mathrm{R} 50^{\mathrm{d}}$ & $\mathrm{CO}(\mathrm{s})+\mathrm{OH}(\mathrm{s}) \rightarrow \mathrm{COOH}(\mathrm{s})+\mathrm{Pt}(\mathrm{s})$ & $3.00 \times 10^{17}$ & 0.470 & $\begin{array}{l}23884.2-19824.2 \theta \mathrm{O}(\mathrm{s}) \\
-10509.2 \theta^{\mathrm{b}}+14091.9 \theta_{\mathrm{H}_{2} \mathrm{O}(\mathrm{s})} \mathrm{b}\end{array}$ \\
\hline R51 & $\mathrm{COOH}(\mathrm{s})+\mathrm{Pt}(\mathrm{s}) \rightarrow \mathrm{CO}_{2}(\mathrm{~s})+\mathrm{H}(\mathrm{s})$ & $1.43 \times 10^{18}$ & 0.580 & $955.4+1433.1 \theta_{\mathrm{H}(\mathrm{s})}$ \\
\hline R52 & $\mathrm{CO}_{2}(\mathrm{~s})+\mathrm{H}(\mathrm{s}) \rightarrow \mathrm{COOH}(\mathrm{s})+\mathrm{Pt}(\mathrm{s})$ & $6.51 \times 10^{19}$ & -0.110 & $1671.9-1433.1 \theta_{\mathrm{H}(\mathrm{s})}$ \\
\hline R53 & $\mathrm{CO}(\mathrm{s})+\mathrm{H}_{2} \mathrm{O}(\mathrm{s}) \rightarrow \mathrm{COOH}(\mathrm{s})+\mathrm{H}(\mathrm{s})$ & $2.47 \times 10^{18}$ & 0.490 & $\begin{array}{l}24362.3+1194.2 \theta_{H(s)}+12420.0 \theta_{\mathrm{OH}(\mathrm{s})}{ }^{\theta} \mathrm{CO}(\mathrm{s}) \\
-1194.2 \theta_{\mathrm{H}_{2} \mathrm{O}(\mathrm{s})}-7404.2 \theta_{\mathrm{CO}(\mathrm{s})}\end{array}$ \\
\hline R54 & $\mathrm{COOH}(\mathrm{s})+\mathrm{H}(\mathrm{s}) \rightarrow \mathrm{CO}(\mathrm{s})+\mathrm{H}_{2} \mathrm{O}(\mathrm{s})$ & $3.96 \times 10^{19}$ & -0.030 & $\begin{array}{l}4776.9-1910.8 \theta H(s)-12420.0 \theta \mathrm{OH}(\mathrm{s}){ }^{\theta} \mathrm{CO}(\mathrm{s}) \\
+1194.2 \theta_{\mathrm{H}_{2} \mathrm{O}(\mathrm{s})}+7404.2 \theta_{\mathrm{CO}}(\mathrm{s})\end{array}$ \\
\hline R55 & $\mathrm{CO}_{2}(\mathrm{~s})+\mathrm{OH}(\mathrm{s}) \rightarrow \mathrm{COOH}(\mathrm{s})+\mathrm{O}(\mathrm{s})$ & $1.48 \times 10^{19}$ & 0.050 & $26273.1-9792.7 \theta O(s)^{\mathrm{b}}+12420.0 \theta_{\mathrm{H}_{2}} \mathrm{O}(\mathrm{s}){ }^{\mathrm{b}}$ \\
\hline R56 & $\mathrm{COOH}(\mathrm{s})+\mathrm{O}(\mathrm{s}) \rightarrow \mathrm{CO}_{2}(\mathrm{~s})+\mathrm{OH}(\mathrm{s})$ & $5.28 \times 10^{18}$ & 0.450 & $7165.4+7165.4 \theta_{O(s)} \mathrm{b}-12420.0 \theta_{\mathrm{H}_{2}} \mathrm{O}(\mathrm{s}) \mathrm{b}$ \\
\hline R57 & $\mathrm{CO}_{2}(\mathrm{~s})+\mathrm{H}_{2} \mathrm{O}(\mathrm{s}) \rightarrow \mathrm{COOH}(\mathrm{s})+\mathrm{OH}(\mathrm{s})$ & $4.22 \times 10^{19}$ & -0.050 & $\begin{array}{l}17196.9+11703.5 \theta_{\mathrm{O}(\mathrm{s})}^{\mathrm{b}}+12420.0 \theta_{\mathrm{OH}(\mathrm{s})}^{\mathrm{b}} \\
-11464.6 \theta_{\mathrm{H}_{2} \mathrm{O}(\mathrm{s})}^{\mathrm{b}}\end{array}$ \\
\hline R58 & $\mathrm{COOH}(\mathrm{s})+\mathrm{OH}(\mathrm{s}) \rightarrow \mathrm{CO}_{2}(\mathrm{~s})+\mathrm{H}_{2} \mathrm{O}(\mathrm{s})$ & $1.75 \times 10^{18}$ & 0.560 & $\begin{array}{l}11942.3-21257.5 \theta_{\mathrm{O}(\mathrm{s})}^{\mathrm{b}}-12420.0 \theta_{\mathrm{OH}(\mathrm{s})}^{\mathrm{b}} \\
+16002.7 \theta_{\mathrm{H}_{2} \mathrm{O}(\mathrm{s})}^{\mathrm{b}}\end{array}$ \\
\hline \multicolumn{5}{|c|}{ Reactions of $\mathrm{HCOO}$ on $\mathrm{Pt}$} \\
\hline R59 & $\mathrm{CO}_{2}(\mathrm{~s})+\mathrm{H}(\mathrm{s}) \rightarrow \mathrm{HCOO}(\mathrm{s})$ & $6.50 \times 10^{19}$ & -0.08 & $17913.5-3105.0 \theta_{\mathrm{H}(\mathrm{s})}{ }^{\mathrm{b}}$ \\
\hline R60 & $\mathrm{HCOO}(\mathrm{s}) \rightarrow \mathrm{CO}_{2}(\mathrm{~s})+\mathrm{H}(\mathrm{s})$ & $8.16 \times 10^{9}$ & 0.420 & 0.0 \\
\hline R61 & $\mathrm{CO}_{2}(\mathrm{~s})+\mathrm{OH}(\mathrm{s})+\mathrm{Pt}(\mathrm{s}) \rightarrow \mathrm{HCOO}(\mathrm{s}, \mathrm{s})+\mathrm{O}(\mathrm{s})$ & $5.80 \times 10^{28}$ & -0.340 & $36304.6-16958.1 \theta_{\mathrm{O}(\mathrm{s})}{ }^{\mathrm{b}}+25078.8 \theta_{\mathrm{H}_{2}} \mathrm{O}(\mathrm{s}){ }^{\mathrm{b}}$ \\
\hline R62 & $\mathrm{HCOO}(\mathrm{s}, \mathrm{s})+\mathrm{O}(\mathrm{s}) \rightarrow \mathrm{CO}_{2}(\mathrm{~s})+\mathrm{OH}(\mathrm{s})+\mathrm{Pt}(\mathrm{s})$ & $1.48 \times 10^{20}$ & -0.160 & 0.0 \\
\hline R63 & $\mathrm{CO}_{2}(\mathrm{~s})+\mathrm{H}_{2} \mathrm{O}(\mathrm{s})+\mathrm{Pt}(\mathrm{s}) \rightarrow \mathrm{HCOO}(\mathrm{s}, \mathrm{s})+\mathrm{OH}(\mathrm{s})$ & $1.07 \times 10^{29}$ & -0.360 & $\begin{array}{l}25556.5+11942.3 \theta_{\mathrm{O}(\mathrm{s})}^{\mathrm{b}}+12420.0 \theta_{\mathrm{OH}(\mathrm{s})}^{\mathrm{b}} \\
-11464.6 \theta_{\mathrm{H}_{2} \mathrm{O}(\mathrm{s})}^{\mathrm{b}}\end{array}$ \\
\hline R64 & $\mathrm{HCOO}(\mathrm{s}, \mathrm{s})+\mathrm{OH}(\mathrm{s}) \rightarrow \mathrm{CO}_{2}(\mathrm{~s})+\mathrm{H}_{2} \mathrm{O}(\mathrm{s})+\mathrm{Pt}(\mathrm{s})$ & $\begin{array}{r}2.41 \times 10^{19} \\
19\end{array}$ & 0.070 & $\begin{array}{l}3105.0-21018.4 \theta_{\mathrm{O}(\mathrm{s})} \mathrm{b}-12420.0 \theta_{\mathrm{OH}(\mathrm{s})} \mathrm{b} \\
+16002.7 \theta_{\mathrm{H}_{2}} \mathrm{O}(\mathrm{s})\end{array}$ \\
\hline
\end{tabular}

